Review

\title{
Clay as a Sustainable Binder for Concrete-A Review
}

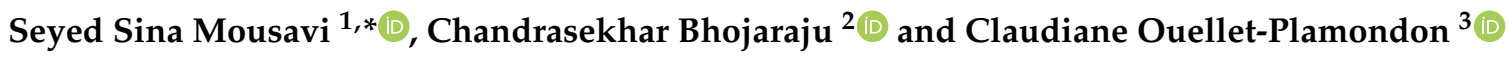 \\ 1 Department of Civil Engineering, Babol Noshirvani University of Technology, P.O. Box 484, \\ Babol 47148-71167, Iran \\ 2 Department of Civil Engineering, St Joseph Engineering College, Vamanjoor, Mangaluru 575028, India; \\ chandrasekhar.b@sjec.ac.in \\ 3 Department of Construction Engineering, École de Technologie Supérieure, 1100 Notre-Dame West, \\ Montreal, QC H3C 1K3, Canada; claudiane.ouellet-plamondon@etsmtl.ca \\ * Correspondence: seyedsina.m@gmail.com
}

check for updates

Citation: Mousavi, S.S.; Bhojaraju, C.; Ouellet-Plamondon, C. Clay as a Sustainable Binder for Concrete-A Review. Constr. Mater. 2021, 1 , 134-168. https://doi.org/10.3390/ constrmater1030010

Received: 26 May 2021

Accepted: 20 September 2021

Published: 29 September 2021

Publisher's Note: MDPI stays neutral with regard to jurisdictional claims in published maps and institutional affiliations.

Copyright: (C) 2021 by the authors Licensee MDPI, Basel, Switzerland. This article is an open access article distributed under the terms and conditions of the Creative Commons Attribution (CC BY) license (https:/ / creativecommons.org/licenses/by/ $4.0 /)$.

\begin{abstract}
The negative environmental impacts of Portland cement as a binder in the construction industry have created a growing impetus to develop sustainable alternative binders. Various types of clay have been considered as potential cement replacements. The impact of clays as cement replacement depends on the dosage and treatment methods. This paper presents a comprehensive review to determine the effects of different types of clay on the fresh and hardened properties of concrete mixtures by analyzing the experimental database reported by the literature, including raw, calcined, modified, nano, and organo. This study intends to show the process of optimizing the use of clay in concrete, the reason behind converting raw clay to modified types, and research gaps through a comparison study between different types of clays. The present review study shows that clay-based concrete mixtures have higher thixotropy and yield stress values, improving shape stability. This results in lower early-age shrinkage of the concrete. However, the high floc strength of clay-based concrete causes a reduction in flowability. Treatment methods of raw clay, such as calcination and nano-sized clay particles, improve concrete compressive strength. General results of the previous studies highlight that all types of clay investigated positively affect the resistance of concrete to environmental attack.
\end{abstract}

Keywords: nano-clay; metakaolin; bentonite; organo-clay; sustainable concrete; durability

\section{Introduction}

Global demand for cement and concrete has increased significantly in recent years due to the rapid expansion of countries and continued population growth throughout the world [1,2]. Global cement production has increased almost 4-fold since 1990 [3]. This has led to the expansion of various industries connected to concrete as one of the leading construction industry components, starting from raw material extraction and increased fossil fuel consumption for material processing and cement production [4]. This heightened demand has increased the cost of cement by more than $150 \%$ over the past ten years and threatens significant environmental impacts which need to be mitigated [5]. Hence, improvements in concrete sustainability have become a principal concern of researchers in the construction industry.

Most of the binding materials used in concrete are based on Portland cement, which is the hydraulic binder (hardening when combined with water), produced through an energyintensive process [6]. The process emits large amounts of greenhouse gases, an estimated $5-8 \%$ of the world's anthropogenic $\mathrm{CO}_{2}$ [7]. This trend is expected to increase in the coming decades as the countries continue to increase their concrete demand [8]. It is predicted that cement production could represent $10 \%$ to $15 \%$ of global $\mathrm{CO}_{2}$ emissions [9]. The cement industry has made substantial development in improving its production efficiency [9] as well as reducing its environmental impact [10]. Automation of the manufacturing of lime in modern cement kilns and increased use of alternative and sustainable fuel 
sources are the key improvements in the cement industry for reducing energy consumption and associated $\mathrm{CO}_{2}$ emissions [11]. However, these initiatives have been outpaced by the dramatic increases in demand, and further developments are required to reduce the environmental impacts and costs.

To address the sustainability problems facing the concrete industry, there is an urgent need to develop concrete compositions with reduced cement content. Recent advancements in packing optimization and the development of water-reducing superplasticizers have already contributed to more sustainable concrete use [12]. Furthermore, the cement industry has already achieved impressive improvements by developing supplementary cementitious materials (SCMs) and naturally sourced blending materials, such as silica fume (SF), natural pozzolan, fly ash, and limestone, to reduce the required cement content in concretes. Pozzolanic and filling effects are the two essential characteristics of these mineral admixtures. To date, a large variety of products have been used as cementitious materials, with a wide range of chemical compositions, which are placed in $\mathrm{CaO}-\mathrm{SiO}_{2}-$ $\mathrm{Al}_{2} \mathrm{O}_{3}$ ternary phase diagram [13]. Although industrial by-products or waste (e.g., fly ashes and blast furnace slags) are widely used to replace part of the cement clinker, the availability of these SCMs is limited by their production as by-products of power plants or blast furnace industries $[14,15]$. Furthermore, their efficiency to replace clinker has been studied by previous researchers who have concluded that they cannot be considered a global alternative to cement [16]. Thus, there is a growing tendency to find new alternative inorganic binders from local sources for replacing cement in concrete structures. Raw earthbased materials are promising options for low-cost and environmentally friendly building materials $[17,18]$. Among such materials, clays are an abundant option that can be effective as mineral additives or in blended concrete in many places of the world [19]. Clays are a rich source of alumina and silica, which can cause a pozzolanic reaction under the proper conditions. Clays have already been shown to have excellent pozzolanic properties under specific calcination conditions or surface modifications [14,19]. For these reasons, clays in their raw, calcined, and modified forms are important cement-replacement alternatives for the development of sustainable concretes with lower costs and environmental impacts.

This review discusses the field of clay-based concrete from a physical standpoint, emphasizing both fresh and hardened state properties, which are critical to concrete applications. Thermodynamic and kinetic reactions are possible to be discussed but are outside the scope of the present study. Instead, the current review will focus on a brief survey of the clay-based concrete, including the efforts made before 2000, recent advancements, and existing gaps in scientific understanding, which will be discussed to present a clear path for future research in this field.

\section{Scientific Databases Used}

This study uses different scientific databases, including journal papers, conferences, and dissertations, to reveal the effect of using clay in concrete. Various credible sites have been considered for extracting related research. The authors have tried to gather journal papers mentioned in the largest database of peer-reviewed literature. Although the authors intended to use the current state-of-art of research in this study, they did not want to ignore the impressive old research (Figure 1). About 27.7\% and 38.3\% of the referenced research studies are devoted to 2010-2015 and 2015-2021, respectively. Thus, the present study uses many novel types of research in this field to maintain both novelty and comprehensiveness. Figure 1 shows the growing interest of researchers in recent years to identify new generations of clays (mostly calcined clay and nano-clay) compared to studies performed before 2000. Three subsections are considered in this research to accurately determine the effect of adding clay to the concrete mixture, including fresh properties, hardened properties, and durability (Figure 2). Flowability, rheology, and early-age shrinkage are the main three characteristics of fresh-state concrete selected to be discussed in Section 3. The compressive strength of concrete and bond strength between reinforcing bars and surrounding concrete are the only properties of the hardened state, 
considered in Section 4. To review the effect of clay on the ability of concrete to resist deterioration from the environment, Section 5 is divided into four subsections. The authors intend to monitor the impact of clay on the performance of concrete from the beginning to service life. Research related to each section has been precisely explained. The figures have been strictly selected to clarify better the findings of the researchers.

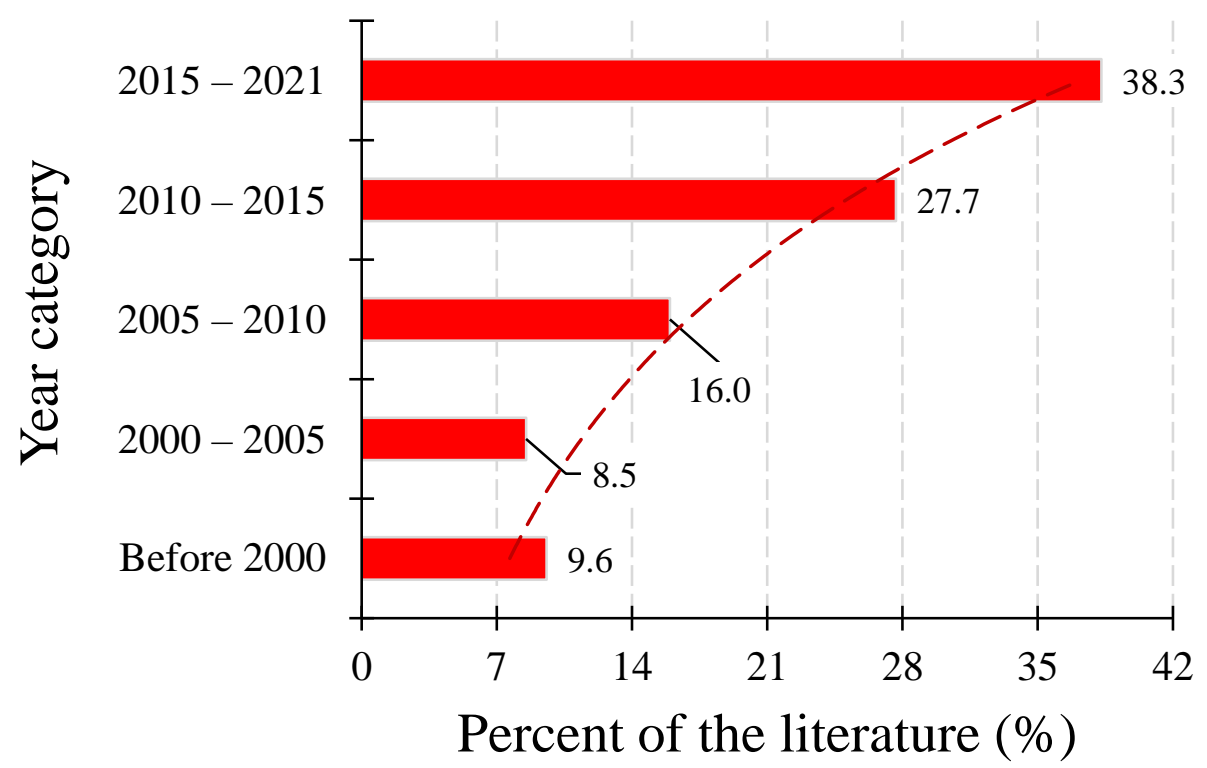

Figure 1. References used in the present study (produced entirely by the authors through analyzing the literature).

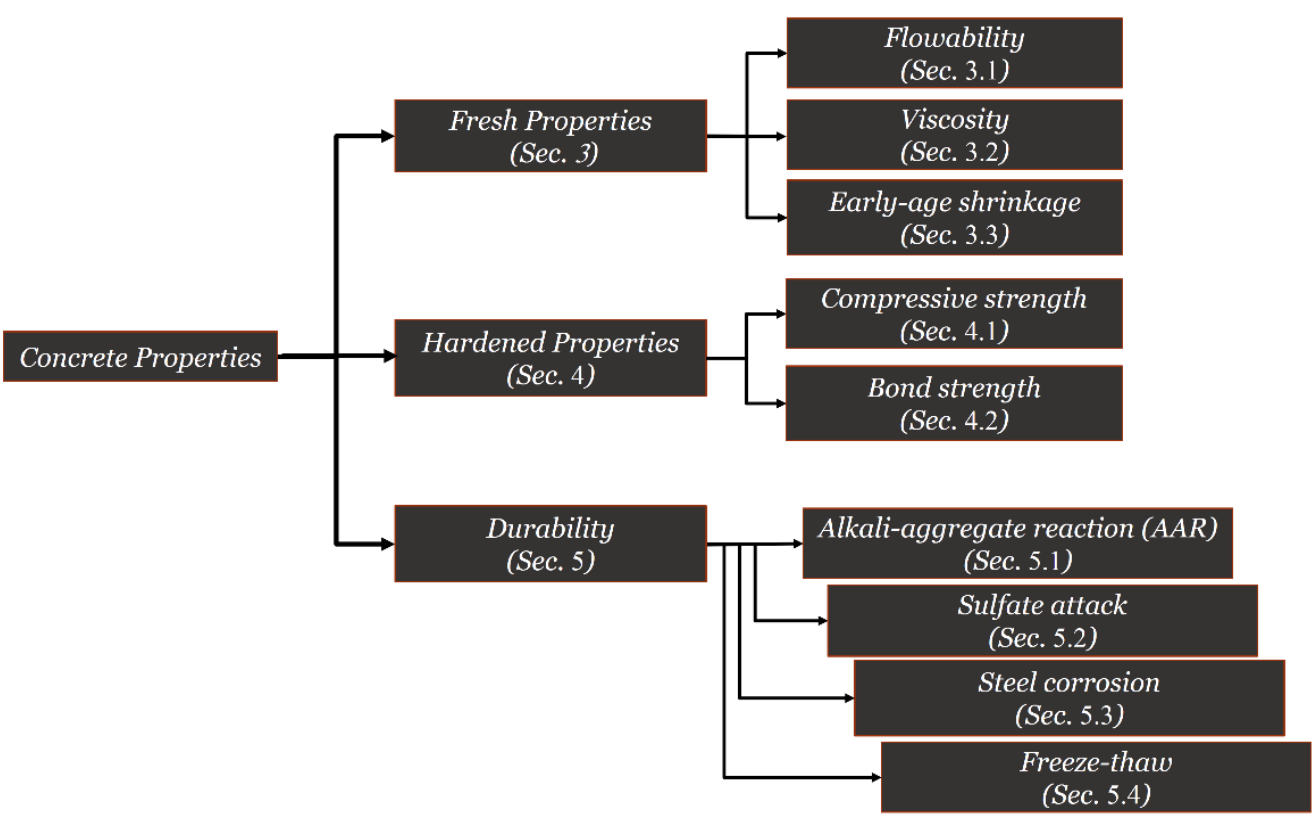

Figure 2. Overview of the sections considered in the present paper.

It is worth mentioning that references related to the limestone calcined clay cement $\left(\mathrm{LC}^{3}\right)$ are out of the scope of the present study [20]. This study mainly consists of using clay minerals along with the calcined types without using limestone, fly ash, and slag. Moreover, the present study intends to concentrate on studies conducted on separately adding calcined clays to the concrete instead of a partial replacement of clinker in cement, which is the main issue in $\mathrm{LC}^{3}$ technology. A more comprehensive review is necessary for future works to review the $\mathrm{LC}^{3}$ technology. 


\section{Properties of Clay}

Clay is a product of the erosion of precursor minerals such as quartz, feldspar, or other clay types in minor amounts and is plentifully accessible close to the earth's surface [21,22]. Feldspar contains oxide, second metal oxide, and silicon dioxide [23]. Kaolinite, montmorillonite (MMT), and illite are the three common standard clay minerals. Kaolinite-contained clay is the most suitable clay type in tropical and subtropical environments [7]. Each clay particle or micelle has a hexagonal lamellar crystalline structure, whose structure is a combination of aluminosilicate sheets (an octahedral $(\mathrm{O})$ and tetrahedral $(\mathrm{T})$ sheet). A silica sheet is composed of silicon atoms in tetrahedral coordination, where three of the four oxygen atoms in each tetrahedron are shared to form a hexagonal net. Furthermore, alumina sheets are composed of aluminum atoms in octahedral coordination with oxygen or hydroxyls $[14,24]$. Clay surfaces are charged due to the isomorphous cation replacement by cations of lower valence [25]. The surface charge density depends on the clay type, $\mathrm{pH}$ value, and electrolyte composition [24,26]. As discussed before, (i) around silicon cores: layers are surrounded by oxygenation; (ii) in the case of aluminum cores, by hydroxyl (ions) groups $(-\mathrm{HO})$. The silicon oxide layers have the strongest negative charge, which endows them with a high inter-lamellar binding force [27-29]. These interchangeable cations, a positively charged ion, significantly affect the binding force and compressive strength of clay-based earth material [22,30].

As shown in Figure 3, six types of clay have been considered by the literature, including raw clay, metakaolin, bentonite, nano-clay, organo-clay, and other calcined clays. The authors of this study have tried their best to consider the fundamental research related to clay-based concrete. Moreover, Figure 3 illustrates that previous research firmly focused on using metakaolin, nano-clay, and raw clay for use in concrete. Other calcined clays, bentonite, and organo-clay are in the later levels of use. Two kinds of references have been used in this study, including general references for an additional explanation about concrete and specific references related to clay-based concrete. Statistical information presented in Figure 3 is related to the specific references of clay-based concrete (percent per $100 \%$ of clay papers). In the first years of studying clay-based concrete, researchers have widely considered raw materials for use in cementitious materials. However, metakaolin has been the most interesting calcined clay in this field of study. In recent years, there is a growing tendency to use other types of clay in concrete, such as nano-clay, organo-clay, and other calcined clay. $\mathrm{CaO}-\mathrm{Al}_{2} \mathrm{O}_{3}-\mathrm{SiO}_{2}$ ternary diagram of clay types is shown in Figure 4. This section intends to describe these types of clay as follows briefly.

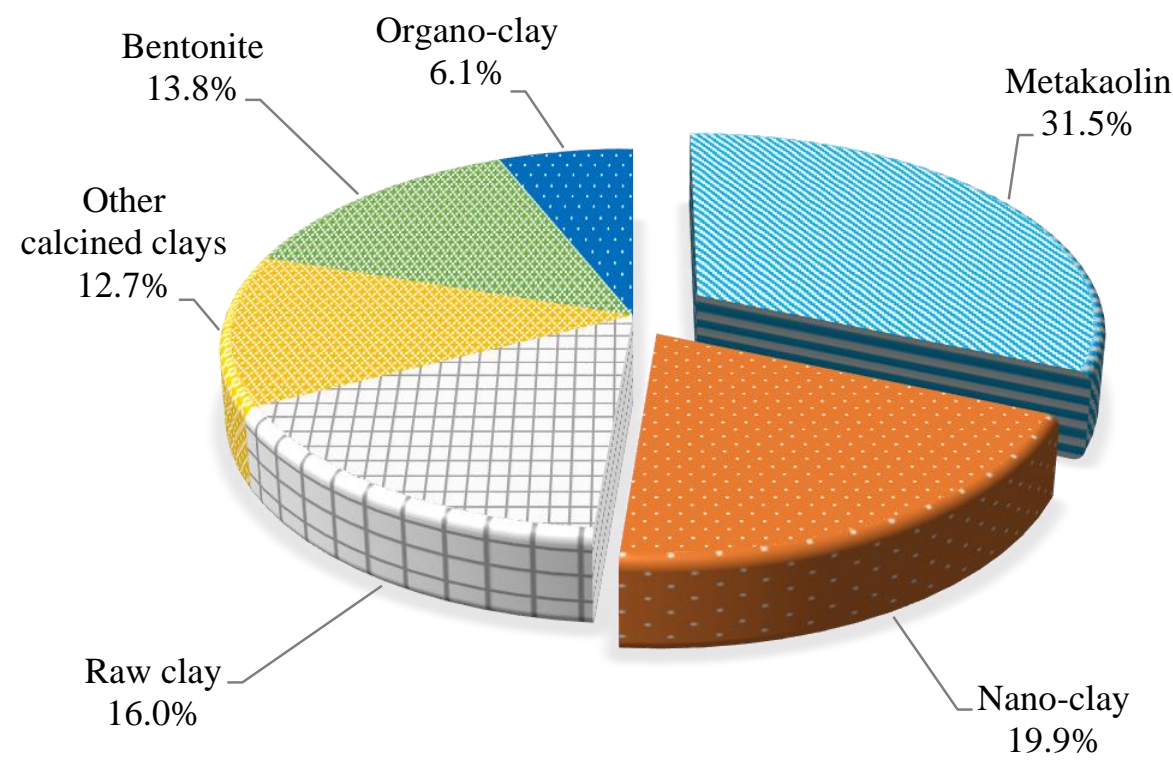

Figure 3. Types of clay used in the literature reviewed (produced entirely by the authors through analyzing the literature). 


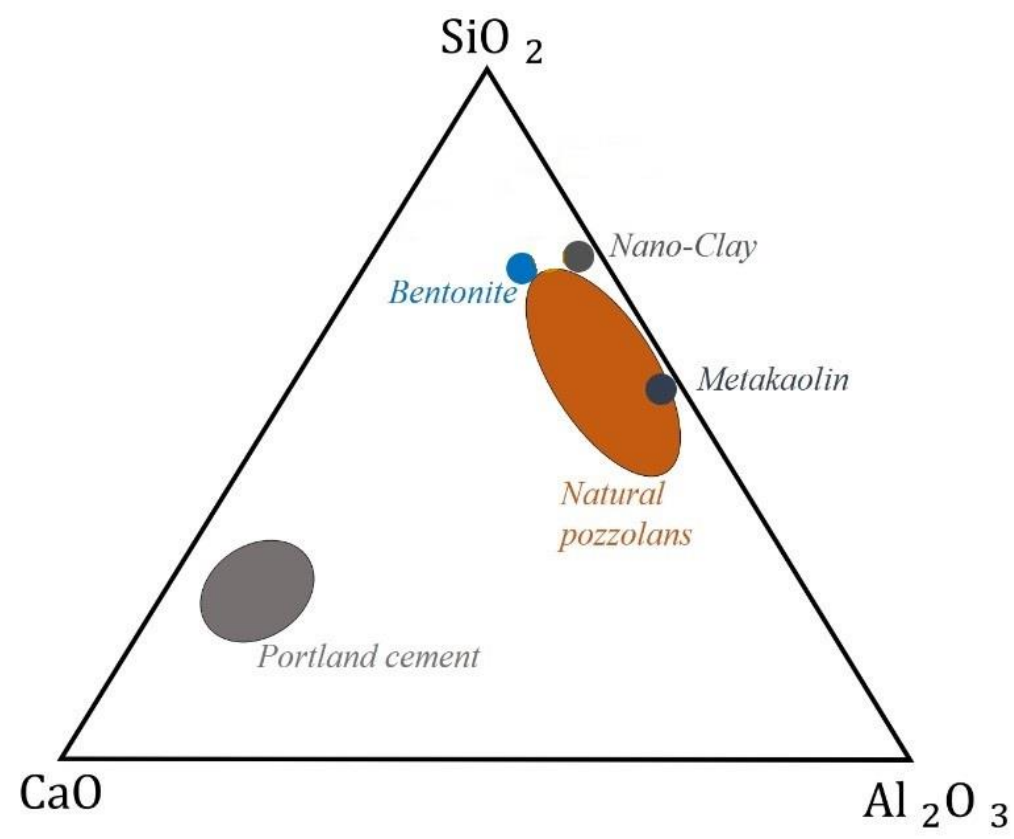

Figure 4. $\mathrm{CaO}-\mathrm{Al}_{2} \mathrm{O}_{3}-\mathrm{SiO}_{2}$ ternary diagram of clay types. (Reproduced and improved entirely by the authors through changing the diagram reported by Rossen (2014) [31]).

Raw clays consist of minerals, with no additional processes being utilized for preparing them. Quartz, kaolinite, illite, silica, sepiolite, montmorillonite, muscovite, and concresol are the clay minerals that have been considered in the literature.

Calcination of clay minerals means the process of dehydroxylation of ultrafine raw clay by thermal activation in high temperature in the kiln, which results in driving off the chemically bound water, breaking down the crystal structure, and changing into a highly reactive transition phase. Most of the previous research has concentrated on the calcination of kaolinite clays at various temperatures. Different temperatures have been considered in the process of calcination by the literature. For example, Palomo et al. (1992) [32] found $600-700{ }^{\circ} \mathrm{C}$ for calcined kaolinite clay. Zibouche et al. (2009) [33] and Chareerat et al. (2006) [34] selected 800 and $600{ }^{\circ} \mathrm{C}$, respectively, as the best calcination temperature. Calcination temperature affects the fresh and hardened properties of cementitious material [35]. One of the most applicable products of kaolinite $\left(\mathrm{Al}_{2} \mathrm{Si}_{2} \mathrm{O}_{5}(\mathrm{OH})_{4}\right)$ calcination is metakaolin as an anhydrous alumino-silicate $\left(\mathrm{Al}_{2} \mathrm{Si}_{2} \mathrm{O}_{7}\right)$. Metakaolin is a dehydroxylated form of the clay mineral kaolinite obtained by calcination at a temperature between 500 and $800{ }^{\circ} \mathrm{C}$. The major constituents of metakaolin are silica oxide $\left(\mathrm{SiO}_{2}\right)$ and alumina oxide $\left(\mathrm{Al}_{2} \mathrm{O}_{3}\right)$. The typical chemical compositions of metakaolin are shown in Table $1 . \mathrm{SiO}_{2}$ reacts with $\mathrm{Ca}(\mathrm{OH})_{2}$ in concrete to produce secondary calcium silicate hydrate (CSH) gel at ambient temperature. Apart from that, the alumina in metakaolin reacts with calcium hydroxide $(\mathrm{CH})$ to produce additional alumina-containing phases, including $\mathrm{C}_{4} \mathrm{AH}_{13}, \mathrm{C}_{2} \mathrm{ASH}_{8}$, and $\mathrm{C}_{3} \mathrm{AH}_{6}$ [36]. The recommended optimum activation temperature of metakaolin varies between 600 and $850{ }^{\circ} \mathrm{C}$ for the varying duration (Table 2). The importance of calcination temperature was highlighted and prioritized in geopolymer cement. For instance, the compressive strength of geopolymer cement paste increases with the increase of the calcination temperature of kaolinite clays between 500 and $700{ }^{\circ} \mathrm{C}$ but drops above $700{ }^{\circ} \mathrm{C}$ [35]. 
Table 1. Compounds of different clay types (average values of references).

\begin{tabular}{ccccc}
\hline Compound (\%) & Raw Clay & Metakaolin & Bentonite & Nano-Clay \\
\hline $\mathrm{SiO}_{2}$ & 53.24 & 52.32 & 53.91 & 57.81 \\
$\mathrm{Al}_{2} \mathrm{O}_{3}$ & 28.27 & 43.06 & 16.90 & 20.46 \\
$\mathrm{Fe}_{2} \mathrm{O}_{3}$ & 2.10 & 1.70 & 7.19 & 2.58 \\
$\mathrm{MgO}$ & 1.11 & 0.14 & 4.22 & 1.243 \\
$\mathrm{CaO}$ & 1.88 & 0.09 & 7.14 & 0.763 \\
$\mathrm{Na}{ }_{2} \mathrm{O}$ & 1.07 & 0.17 & 0.60 & 0.8 \\
$\mathrm{~K}_{2} \mathrm{O}$ & 1.56 & 0.38 & 2.33 & 0.86 \\
$\mathrm{SO}_{3}$ & 0.13 & 0.1 & 0.12 & - \\
$\mathrm{TiO}_{2}$ & 0.38 & 0.67 & 1.12 & 1.28 \\
$\mathrm{P}_{2} 0_{5}$ & - & 0.11 & 0.51 & - \\
$\mathrm{MnO}$ & - & - & 0.11 & - \\
$\mathrm{Cr}_{2} \mathrm{O}_{3}$ & - & - & 0.01 & - \\
$\mathrm{ZnO}_{\mathrm{V}_{2} \mathrm{O}_{5}}$ & - & - & 0.17 & - \\
$\mathrm{H}_{2} \mathrm{O}$ & - & - & 0.07 & - \\
$\mathrm{CO}_{2}$ & - & - & - & - \\
\hline Loss on ignition (LOI) & 12.74 & 0.80 & 10.42 & 14.23 \\
\hline References used & {$[37-40]$} & {$[41-50]$} & {$[4,5,51-56]$} & {$[57-59]$} \\
\hline
\end{tabular}

Table 2. Thermal treatment recommended for producing metakaolin.

\begin{tabular}{cccc}
\hline Reference & $\begin{array}{c}\text { Calcination Temperature } \\
\left({ }^{\circ} \mathbf{C}\right)\end{array}$ & Heating Time (min) & More Explanation \\
\hline Murat and Comel (1983) [60] & $700-850$ & 360 & poor kaolins with a low alunite content \\
kaolin with high alunite content \\
Badogiannis et al. (2005) [61] & 650 & 180 & metakaolin with a high pozzolanic index \\
Mejía et al. (2008) [62] & 850 & $2.0{ }^{\circ} \mathrm{C} / \mathrm{min}$ & - \\
Ilić et al. (2010) [63] & $700-800$ & 90 & - \\
Moodi et al. (2011) [64] & 650 & 60 & metakaolin concrete \\
Salau and Osemeke (2015) [65] & $750-850$ & 60 & metakaolin-based geopolymer concrete \\
Albidah et al. (2020) [66] & 750 & 180 & \\
\hline
\end{tabular}

Bentonite is a highly colloidal ductile clay formed by the alteration of volcanic ash (or glass) in situ and is also considered as a smectite-rich clay (mostly montmorillonite) [67]. Main world bentonite manufacturers (in descending order) include the USA, China, India, Greece, Mexico, Turkey, Iran, Russia, Japan, Brazil, and Germany [68,69]. Recently, researchers have defined bentonite as non-kaolin calcined clays and inexpensive supplementary cementitious materials [21,36,70-74]. Bentonite is composed primarily of montmorillonite and is also non-consolidated sedimentary rock. However, the industrial practice uses the same terms for bentonite and montmorillonite as synonyms [75]. Most commercially available bentonites are the non-swelling type, which is called natural sodium bentonites. To produce such material, the $\mathrm{Ca}^{2+}$ and $\mathrm{Na}^{+}$ions should replace $\mathrm{Mg}^{2+}$ ions, denoted as the technology of "alkaline activation" [75].

Organo-Clay (OC): Several methods can be used to modify clay minerals such as adsorption, ion exchange with inorganic cations and organic cations, binding of inorganic and organic anions, linking of organic compounds, reaction with acids, pillaring by different types of poly(hydroxo metal) cations, intraparticle and interparticle polymerization, and dehydroxylation and calcination [76-78]. Ion exchange with alkyl ammonium ions is the conventional way of preparing OC. Montmorillonite with high cation exchange capacity, swelling behavior, adsorption properties, and large surface area is a good option for preparing OC [77]. OC can act as a successful adsorbent of organic pollutants of industrial waste to enable them to be treated by cement-based stabilization/solidification and reduce the retarding effect of hazardous industrial wastes on cement hydration [79]. The use 
of organo-clay (like modified montmorillonite (OMMT)) in cement as nanoparticles can develop mechanical properties including elastic modulus, compressive strength, and activation energy of stress relaxation [80-82]. This effect depends on the water/solid ratio and the type of modifier used in the OC composition.

Nano-Clay, a layered mineral silicate nanoparticle, is a clay mineral with a phyllosilicate or sheet structure and a thickness of about $1 \mathrm{~nm}$ and surfaces about 50-150 nm in one dimension [83-85]. Nano-clays can be classified into various types of classes such as illite, halloysite, bentonite, kaolinite, montmorillonite, hectorite, and chlorite, based on the morphology of nanoparticles and chemical composition [84]. Modification of nano-clays with ammonium salts causes the production of organo-clays (organically modified nano-clays). However, normal nano-clays and organo-clays are separated from each other in this study.

\section{Fresh Properties of Clay-Based Concrete}

The fresh-state properties of cementitious materials affect today's construction world and the hardened properties of the material in service [86], generating high requirements of fresh cement paste properties, such as workability [87]. Ease of placement, increasing the filling ability, using dense reinforcement in high-congested concrete members, and reducing the cost of vibration in the construction industry are the advantages of using concrete with high workability $[88,89]$. A highly workable concrete with superior segregation resistance needs proper flowability and adequate rheological properties. One of the most common models for determining the rheological properties of cement paste is the Bingham model. Yield stress, plastic viscosity, and thixotropy are the fundamental rheological parameters. As the limit stress of the shear flow, the yield stress is an indispensable rheological constant of fresh concrete and dry granular materials (like soils), which is used to evaluate the flowability or transportability of high workability concrete [90,91]. The yield stress defines the minimum shear stress required to initiate the flow [91]. Another critical parameter for the evaluation of the flowability of cementitious material is viscosity. Plastic viscosity is the macroscopic signature of the flow of water in the porosity of the granular system like concrete, so that tends to relate fresh concrete to water (viscous body). Thixotropy is the property of freshly mixed cement pastes that are thick or viscous under normal conditions but become flow over time when agitated [87]. Thixotropy property depends on the particle flocculation and cement hydration of the cement pastes, which change over time. This section explains how clay admixtures affect the microstructure of cement pastes from a rheological standpoint. Yield stress and thixotropy are used to measure how clay provides opportunities to improve the performance of fresh concrete.

\subsection{Effect of Clays on Fluidity of Concrete}

Previous research has shown that raw materials in concrete, such as clay minerals, seriously affect the dispersion properties of PCEs [40,92-94]. The impurities of clay minerals (such as opal-C, an amorphous crystobalite [95]) along with surface irregularities may affect the dispersing ability of PCEs in concrete [96]. Thus, a novel type of PCE possessing enhanced clay tolerance was found to disperse cement nicely in the presence of clay. Sodium montmorillonite clay affects the dispersion force of PCEs in cement paste and reduces dispersing effectiveness of PCE superplasticizers [97]. Clay affects the flow properties of concrete by increasing solid volume, decreasing liquid volume, and the adsorption of PCE's side chain between the interlayer of clay [40]. In this context, Ouellet-Plamondon et al. (2020) [98] reported that the admixture of C-S-H seeds with a PCE and increases the fluidity of mortar with $20 \%$ replacement of cement with calcined clays. The negative effect of kaolinite on PCE's performance is lower than the effect of bentonite and montmorillonite $[39,99]$. Xiong et al. (2015) [92] reported that adding more than $2 \%$ Na-MMT or adding $4 \%$ kaolin will considerably affect the fluidity of cement pastes. They also showed that the influence order is Na-MMT, kaolin, and illite, in which illite has no severe effect on the dispersion performance of polycarboxylate superplasticizer. Bentonite is also known to adsorb the surfactant used in cement admixtures in its structure made of two tetrahedral silica sheets 
bonded to one central alumina octahedral layer [100]. Pekmezci et al. (2007) [101] focused on optimizing the consolidation properties and shape stability of fresh concrete mixtures. The addition of a very small amount of metakaolin ( $3 \%$ and $6 \%$ weight of the cement) reduces the flow ratio to zero. They attributed this effect to the combined effect of the water absorption of the fine materials and the particle size and particle shape of these materials. They also reported that raw clay and purified magnesium aluminosilicate increase flowability compared with the plain mixture. Kawashima et al. (2012) [102] reported that the plain cement paste (without clay) shows higher fluidity due to a higher degree of deflocculation. They deduced that a significant reduction would happen in fluidity when the clays are pre-dispersed in water. They attributed this effect to the immediate stiffening of the placement of the clay. A similar trend can be seen in other references $[40,93,96,97,99]$. The main reason for this reduction in flowability of the clay-based mixture is the phenomenon of flocculation by which fine particles can combine into floc, and thus a fragile structure is formed. Flocculation is the procedure of transferring coagulated colloids into contact with each other to form larger aggregates [103]. The attractive and repulsive forces are the two common explanations for the flocculation mechanism [87]. The flocculation strength significantly affects the yield stress of fresh cement paste. When the shear stress of the microstructure exceeds the yield stress, flow is initiated, and flocs begin to break down into smaller pieces, resulting in the escape of trapped liquid within the flocs [104]. This process also causes a reduction in the viscosity of the paste $[105,106]$. Flocculation studies have indicated that clays increase floc size and flocculation strength $[86,107,108]$, increasing the viscosity, increasing the level of thixotropy, and decreasing the fluidity of concrete mixtures. Different superplasticizers have been suggested to solve this problem in concrete mixtures $[109,110]$. In this field, Liu et al. (2020) [111] experimentally studied fresh and hardened properties of bentonite-based mortars. They used three different types of bentonite in the experimental program, including sodium bentonite (Na-bent), calcium bentonite (Ca-bent), and magnesium bentonite (Mg-bent). As shown in Figure 5, they found that the fluidity of the mixtures decreases with the addition of bentonite, especially for more than $4 \%$ cement replacement. Among the different types of bentonite, calcium bentonite shows the best performance regarding the fluidity characteristics.

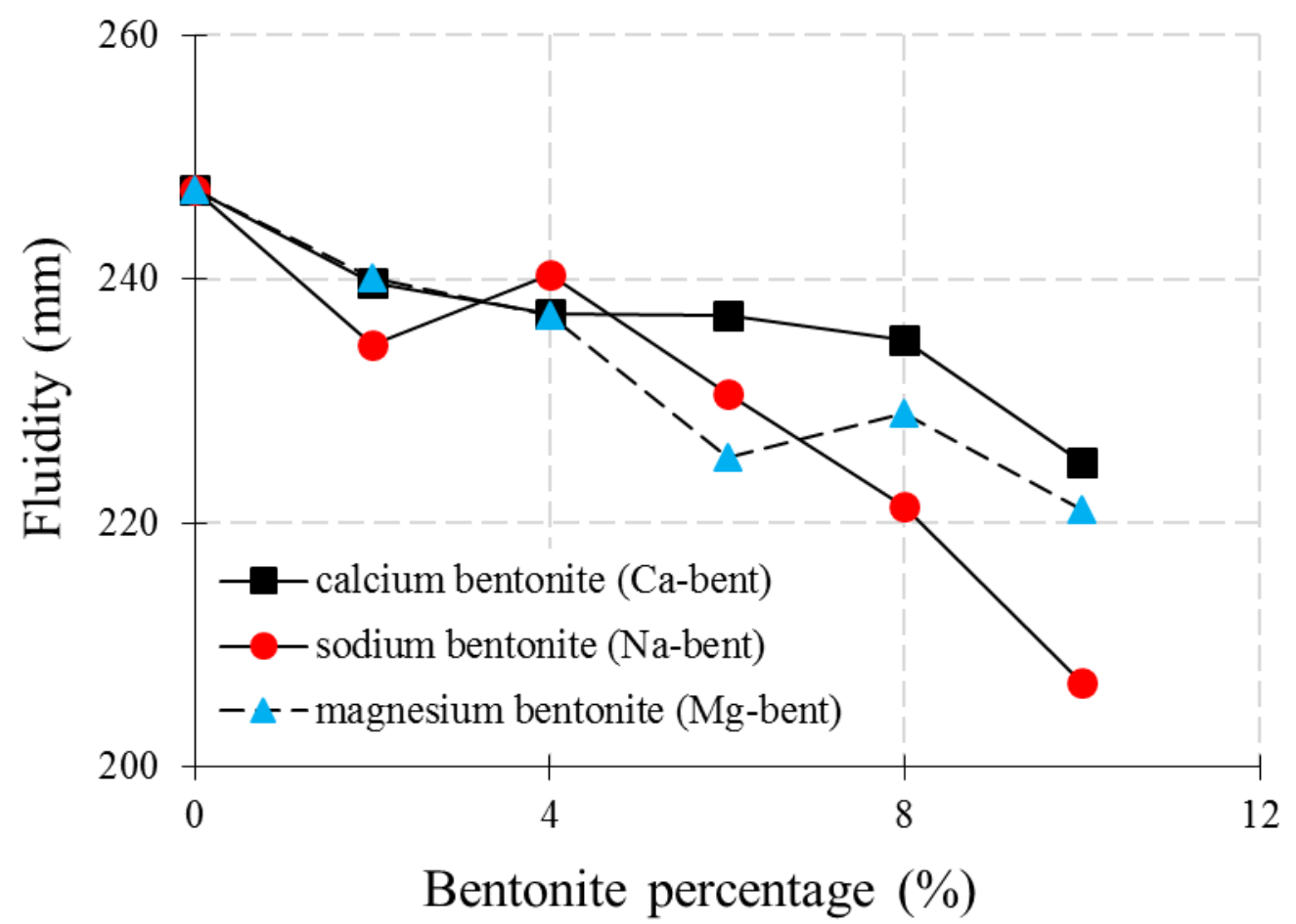

Figure 5. Effect of different types of bentonites on the fluidity of mortar (adapted from Liu et al. (2020) [111]). 


\subsection{Effect of Clays on Viscosity of Concrete}

Concrete in its fresh state can be considered as a fluid material. The flow behavior of concrete can be determined by the Bingham model. Theoretically, the yield stress is the stress at which the fluid starts moving as the viscosity changes between being finite and infinite [112]. Since experimentally determining the yield stress of many fluids is difficult in a transient regime between two steady states (flow and solid) [113], the thixotropy of yield stress fluids has been considered. Thixotropy is the decrease of viscosity of the material in time as a material is made to flow [112]. Quanji (2010) [87] reported that pastes with high reactivity metakaolin replacement have higher thixotropic values, improving the shape stability of the mixture. Similarly, as shown in Figure 6, Quanji et al. (2014) [114] showed that the addition of nano-clay (highly purified magnesium alumino silicate) significantly increases the thixotropy of mixtures for the cases of $1-3 \%$ by mass of cement. Hence, pastes with improved thixotropic behavior can attach to the substrates or maintain the shape right after the casting [87]. Moreover, a high thixotropy mixture has the ability to quickly restore its structure which can reduce formwork pressure. Therefore, it has been demonstrated that with small dosages of clay addition (high-reactivity metakaolin), significant improvements in the shape stability and the cohesiveness of cement pastes can be made $[87,115,116]$. As reported by Krauss (2005) [117], an increase in yield stress occurs with increasing the ratio of clay/cem (cement). Still, clay admixture does not significantly change yield stress when the ratio of water to solid volume is high. However, the yield stress dramatically increases with the clay/cem (cement) ratio when the $V_{W} / V_{S}$ (water to solid volume ratio) ratio is lower than 1.60. In this field, Tregger et al. [106] found that cement pastes containing clays (purified magnesium alumino silicate, kaolinite, illite, quartz, and purified calcined kaolinite) have higher shear yield stress of the suspension $\left(\tau_{y}\right)$, as compared to normal cement paste, showing higher bonds between the particles. They also showed that the compressive yield stresses of clay-based cement pastes are also higher than the normal mixture, indicating larger floc strength. Regarding nanoclays, Kawashima et al. (2012) [102] showed that mixtures containing nano-clays (purified magnesium aluminosilicate, or palygorskite) have greater yield stress and viscosity at equilibrium, while representing comparable structural rebuilding eventually. On the other hand, nano-clay-based mixtures show abrupt influence on thixotropy, probably due to flocculation, but then have little impact over time. Similarly, Dejaeghere et al. (2019) [118] studied the influence of purified palygorskite nano-clay in mixtures containing fly ash and superplasticizers. They found that nano-clay enhances dynamic and static yield stress along with plastic viscosity. This was similarly confirmed by Quanji et al. (2014) [114]. In this field, Wang et al. (2021) [119] reported that using nano attapulgite clay increases the static yield stress in 3D printable cementitious materials, warranting the strength improvement essential by the buildability of materials. As shown in Figure 7, Liu et al. (2018) [120] confirmed these observations and showed that using nano-clay, as a viscosity modifier, significantly improves the plastic viscosity and yield stress of paste, especially for a lower $w / c$. ratio. Following this context, Varela et al. (2020) [121] experimentally studied the influence of four types of nano-clays on rheology of SCC pastes, including attapulgite, bentonite, one sepiolite powder form, and one sepiolite dispersed in water. Generally, they reported that all nano-clays have higher yield stress as compared to the reference mixture. Moreover, among them, nano sepiolites have the highest yield stress [121]. They showed that nano bentonite-contained SCC pastes have $20.5 \%$ and $175.5 \%$ higher yield stress, as compared to the reference SCC paste, for $\mathrm{w} / \mathrm{c}$ ratios of 0.35 and 0.45 , respectively. Similar results regarding the improved yield stress were reported by the literature for metakaolin-based mixtures [122,123]. For instance, Neto et al. (2021) [123] found that pastes with metakaolin demonstrated yield stress values almost 10-12 times greater than those of the reference mixture. This phenomenon may be due to the enormous surface area of the clay materials and the following adsorption of the free water within the mixture. This inhibits lubricating the solid particles and consequently increases the internal friction. 


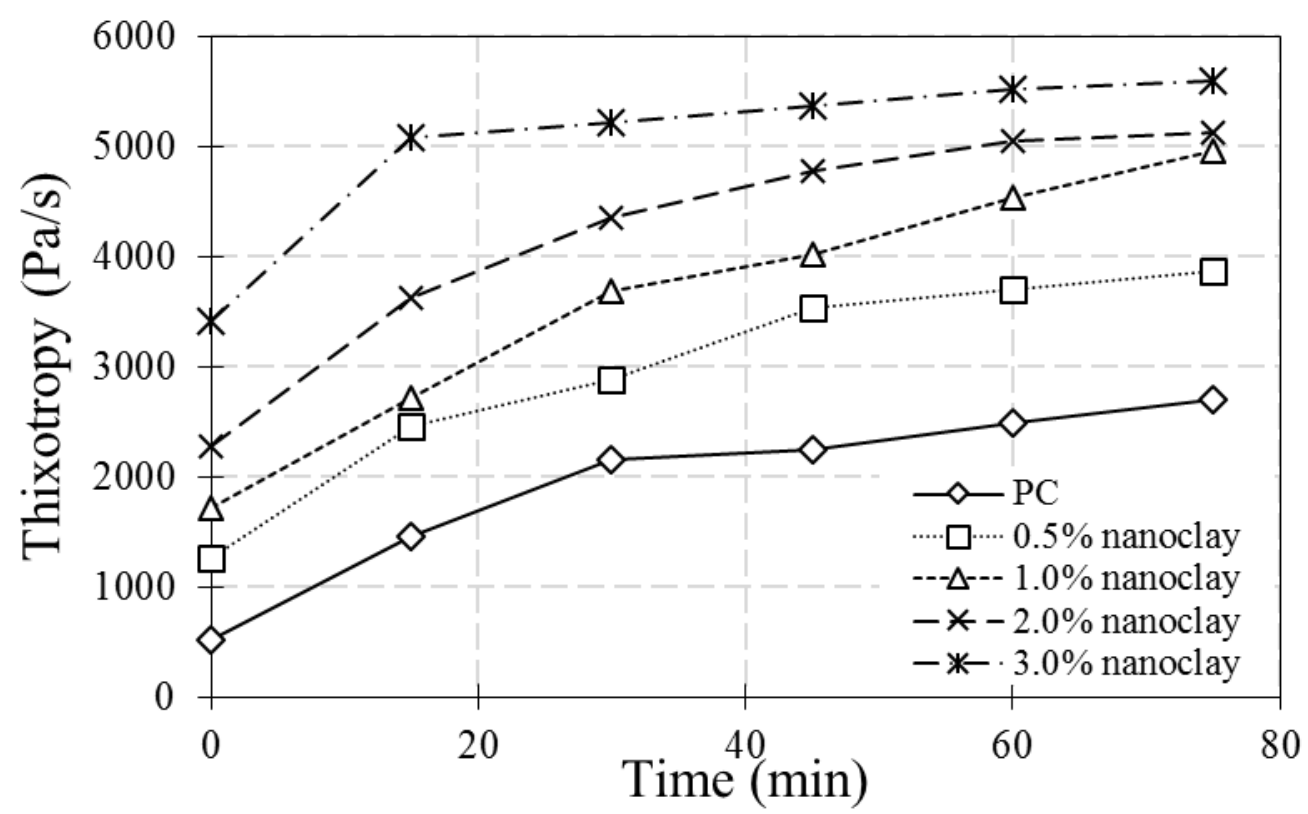

Figure 6. Effect of nano-clay on the thixotropy of cement pastes (adapted from Quanji et al. (2014) [114]).

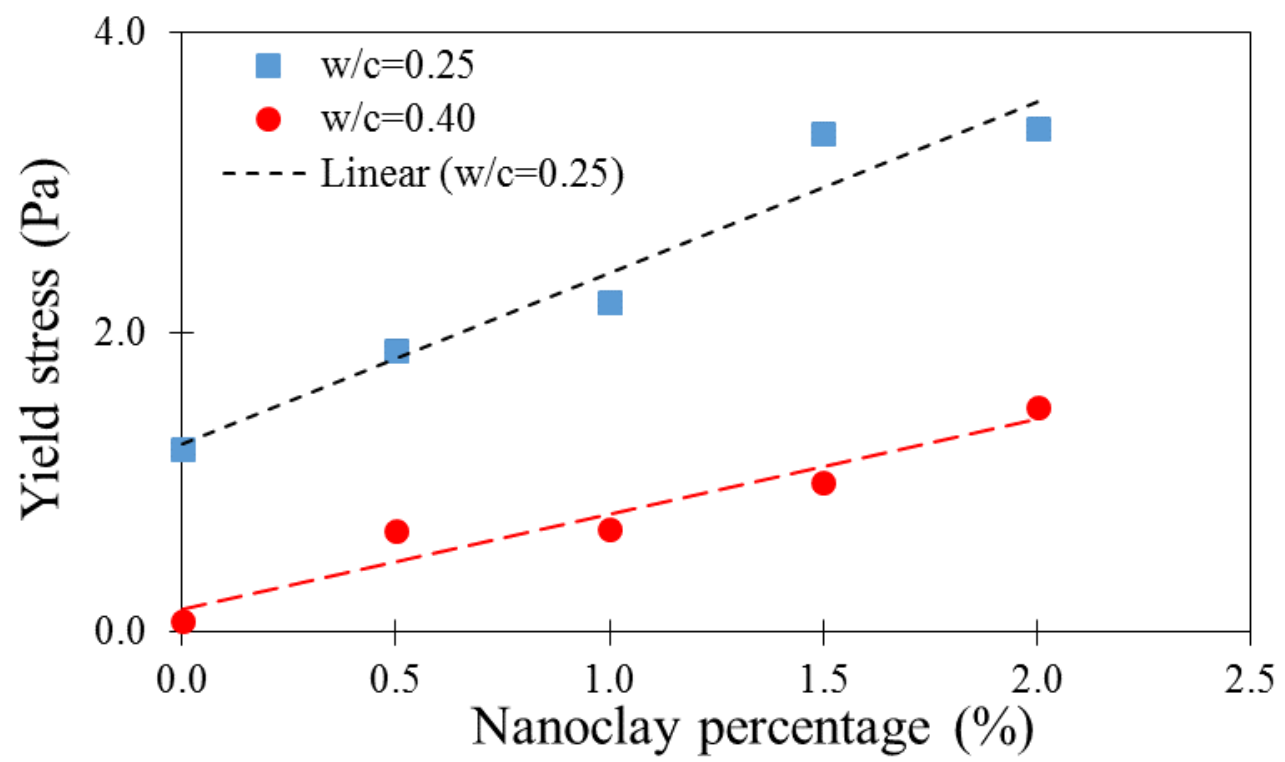

Figure 7. Influence of nano-clay percentage on the yield stress of pastes (adapted from Liu et al. (2018) [120]).

The structural changes within the fresh-state concrete prior to the initial setting can be named as structural rebuilding. Ferron (2008) [124] has presented a hypothesis in which paste matrix governs the initial structural building since the aggregates can be considered as inert materials. It has also been deduced that the rheological properties can be an appropriate way to show structural rebuilding. The rate of structural rebuilding increases with the amount of clay replacement [87]. Aggregation, deflocculating, dispersion, rearrangement, and re-flocculation of cement particles are the key parameters that affect structural rebuilding. Tregger et al. (2010) [106] indicated larger floc strengths for mixes containing clays and smaller floc strengths for mixtures containing high-range water reducers or fly ash. They reported that the strong bonds between the clay particles are due to the absorbing water that would typically help lubricate the microstructure and allow particles to easily slide past each other during shear or compression. In the absence of this lubricating water, 
the suspension would have a higher shear and compressive yield stress [106]. Kawashima et al. (2013) [108] reported that nano-clays have an immediate stiffening effect, governed by flocculation, not water adsorption, but little influence over time. Similarly, Kawashima et al. (2014) [86] studied the impact of nano-clays on the adhesive properties of cement pastes. They reported that by additions of $0.2 \%$ and $0.5 \%$ of clay, cohesion and viscosity increase. The same trend can be seen in other references $[86,102,107,116,125]$.

\subsection{Effect of Clays on Early-Age Shrinkage of Concrete}

Several types of cracks affect the serviceability and durability of concrete, mainly generated by early-age and long-term shrinkage of concrete. Early-age shrinkage represents shrinkage during the first $24 \mathrm{~h}$ after the first contact between cement and water $[126,127]$, and long-term shrinkage extends beyond the first day [128]. Concrete has low strength and strain capacity at an early age, showing sensitive behavior to internal stresses. Hence, internal and microscopic cracks easily imitate and extend at later ages, causing severe problems [129]. Early-age autogenous shrinkage is one of the most effective deformations that generate early-age cracking. Autogenous shrinkage of concrete can be defined as an external volume change (apparent volume change) and the macroscopic volume change that occurs after the initial setting because of the withdrawal of moisture from capillary pores to continue cement hydration reactions. As an internal volume reduction (absolute volume change), chemical shrinkage is the main driving mechanism behind autogenous shrinkage, reducing the volume of hydration products compared with that of the reacting constituents $[130,131]$. Particulate suspension, skeleton formation, and initial hardening are the three main phases of concrete during early age. In the initial phase, concrete is still plastic with no permanent internal structure, and autogenous shrinkage has the same value as the chemical shrinkage. In this phase, concrete is so sensitive to any applied stresses and experiences different deformations. A few hours after casting, initiation of the hydration reaction causes the development of a skeleton. Thus, the setting will occur, and concrete can experience some of the chemical shrinkages. At this moment, autogenous shrinkage starts to be discriminated from chemical shrinkage. Finally, the hardening stage starts, and autogenous shrinkage becomes increasingly restrained due to the stiffening of the cement paste $[126,130,132,133]$. Figure 8 shows the influence of different dosages of metakaolin on the early-age autogenous shrinkage measured from the initial set time. It is clearly demonstrated that the replacement of cement by metakaolin dramatically reduces the autogenous shrinkage. The reduction of autogenous shrinkage could be explained by a dilution effect caused by a decrease in cement content as part of the cement was replaced by metakaolin [46]. Concretes with metakaolin replacement can have a higher effective superplasticizer (based on sulphonated vinyl copolymer) dosage to retard hydration reactions at an early age [46]. Similar results of the effect of clay admixtures on the early-age autogenous shrinkage have been reported in the literature [134-136]. Akcay and Tasdemir (2015) [137] experimentally determined the influence of metakaolin on volumetric autogenous shrinkage of paste samples with different $\mathrm{w} / \mathrm{b}$ ratios. They indicated that with the increasing amount of metakaolin, autogenous shrinkage dramatically decreases. Since the filler effect of metakaolin addition resulted in a denser inner structure, water loss was prevented, and autogenous shrinkage decreased [136]. The same trend has been observed in other references [138]. However, Gao et al. (2012) [38] reported that the addition of clay (nano-clay and metakaolin) increases the autogenous shrinkage at very early ages. They mentioned that this increase is less significant over time. They reported that high specific area and specially charged surfaces are the main reasons for the higher early-age autogenous shrinkage, which allows it to easily gel and adsorb $200 \%$ water by mass. They explained that higher pozzolanic reactivity and the filler effect of metakaolin lead to an increase in autogenous shrinkage related to refining the pore structure [38]. 


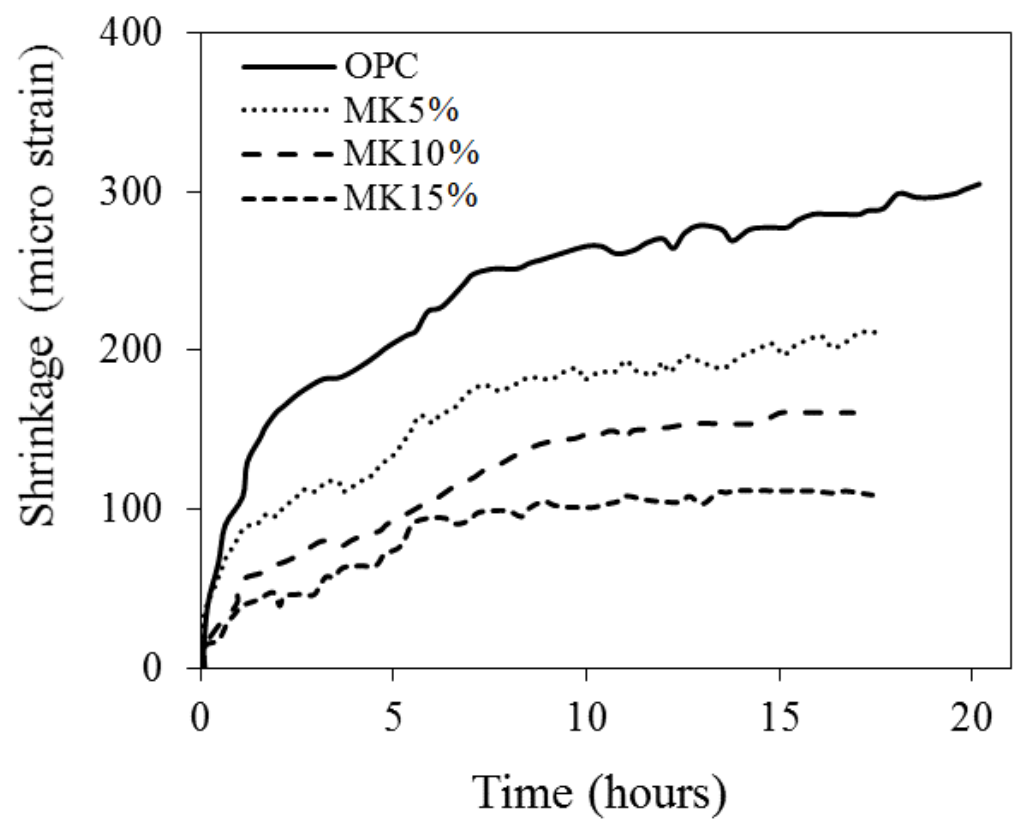

Figure 8. Influence of metakaolin content on the shrinkage of mortar exposed to drying (adapted from Brooks and Johari (2001) [46]).

\section{Hardened Properties of Clay-Based Concrete}

\subsection{Compressive Strength}

Until now, many studies have been performed to evaluate the effect of clay on the compressive strength of concrete. The impacts of different types of clays are separately discussed in the following subsections. It is tried to briefly report both positive and negative results.

\subsubsection{Effect of Raw Clay (vs. Calcined Clay) on Compressive Strength}

Pioneering studies have revealed the effect of raw clays on the performance of cementbased material. Furthermore, additional research has been conducted in the following years. Raw clay materials reduce the compressive strength of concrete [139], while the calcined clays at the optimum increase the compressive strength (Figure 9) [36]. The reactive state of clays depends on the calcination temperature and clay type. The calcination or burning process leads to the loss of hydroxyls, changing the state of clay minerals to a collapsed and disarranged structure [140]. The vast majority of the research has shown the reduction effect of raw clay minerals on the compressive strength, while the results reported by Budelmann et al. (2006) [141] show different trends than the other investigations. The effect is due to the water adsorption on the clay surfaces, so cohesion is reduced, and water for the cement hydration process is retained $[24,36]$. Moreover, the low strength of the clay minerals has a supplementary effect on the compressive strength. The increased water demand is the predominant cause of this adverse effect $[142,143]$. Calcination develops the pozzolanic activity of clay minerals by damaging and destroying the crystal structures of clays, which is a very effective method for solving this problem. The pozzolanic character of the calcined clay that combines $\mathrm{CH}$ to form additional C-S-H explains this increase [14]. 


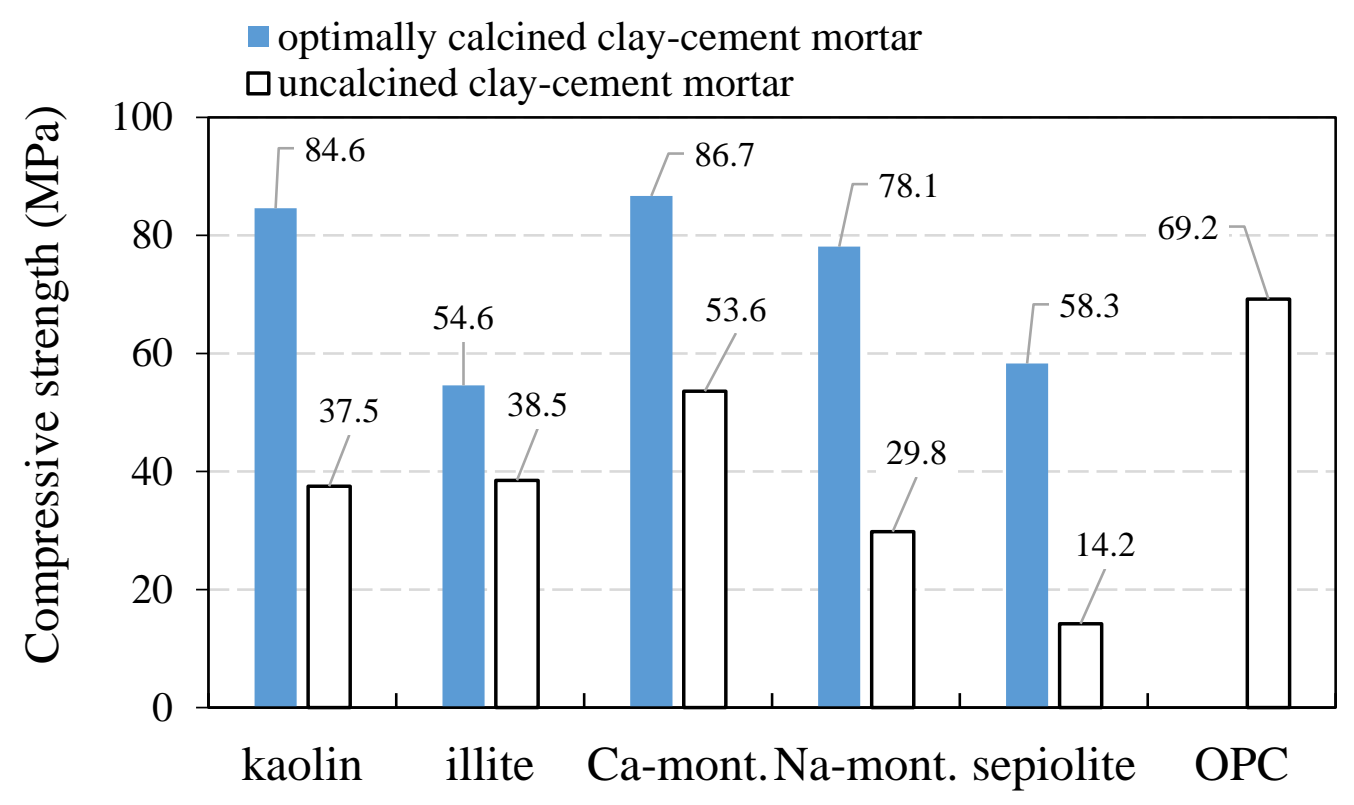

Figure 9. Compressive strength of mortars containing raw clay minerals and calcined clay (mortars with the ratio of cement/clays/sand = 70:30:300 (in weight), adapted from He et al. (1995) [36]).

\subsubsection{Effect of Metakaolin (MK) on Compressive Strength}

Most previous studies have focused on the properties of metakaolin concrete. Metakaolin is a thermally activated alumino-silicate material obtained by calcining kaolin clay $[144,145]$. Ambroise et al. (1985) [146] reported that calcination temperature, ranging from 700 to $850{ }^{\circ} \mathrm{C}$, results in appropriate metakaolin. Calcination below $700{ }^{\circ} \mathrm{C}$ generates less reactive metakaolin, while above $850{ }^{\circ} \mathrm{C}$ the crystallization process reduces the reactivity. Marwan et al. (1992) [147] found $800^{\circ} \mathrm{C}$ to be the optimum calcination temperature of metakaolin. Although natural pozzolans or different types of artificial pozzolans (e.g., fly ash (FA), blast-furnace slag (BFS), and silica fumes (SF)) are secondary products or by-products, metakaolin is a primary product. The production process of metakaolin can then be controlled to attain the desired properties. Metakaolin has high reactivity and can improve the strength of cement and concrete. As shown in Figure 10, El-Din et al. (2017) [148] reported that an optimum dosage of $15 \%$ metakaolin causes $21.96 \%, 27.51 \%$, and $43.34 \%$ increase in the compressive strength of specimens containing $0,0.25 \%$, and $0.50 \%$ steel fiber volume fractions. Similar results were reported by Ding and Li (2002) [149]. The filling effect, the dilution effect, and the pozzolanic reaction of metakaolin with $\mathrm{CH}$ are the main factors influencing the contribution of metakaolin in the compressive strength when it partially replaces cement in concrete [150]. Enhancing the bond between the cement paste and the aggregate particles and increasing the density of the cement paste are the other effects of using metakaolin in the concrete mixture [151]. Metakaolin can prompt the hydration of PC, shorten the setting time of cement, increase the water requirement, increase the fluidity loss of the fresh paste, and also can react with $\mathrm{CH}$ released by cement clinker hydration to produce secondary C-S-H gel inside the cement paste [152]. 


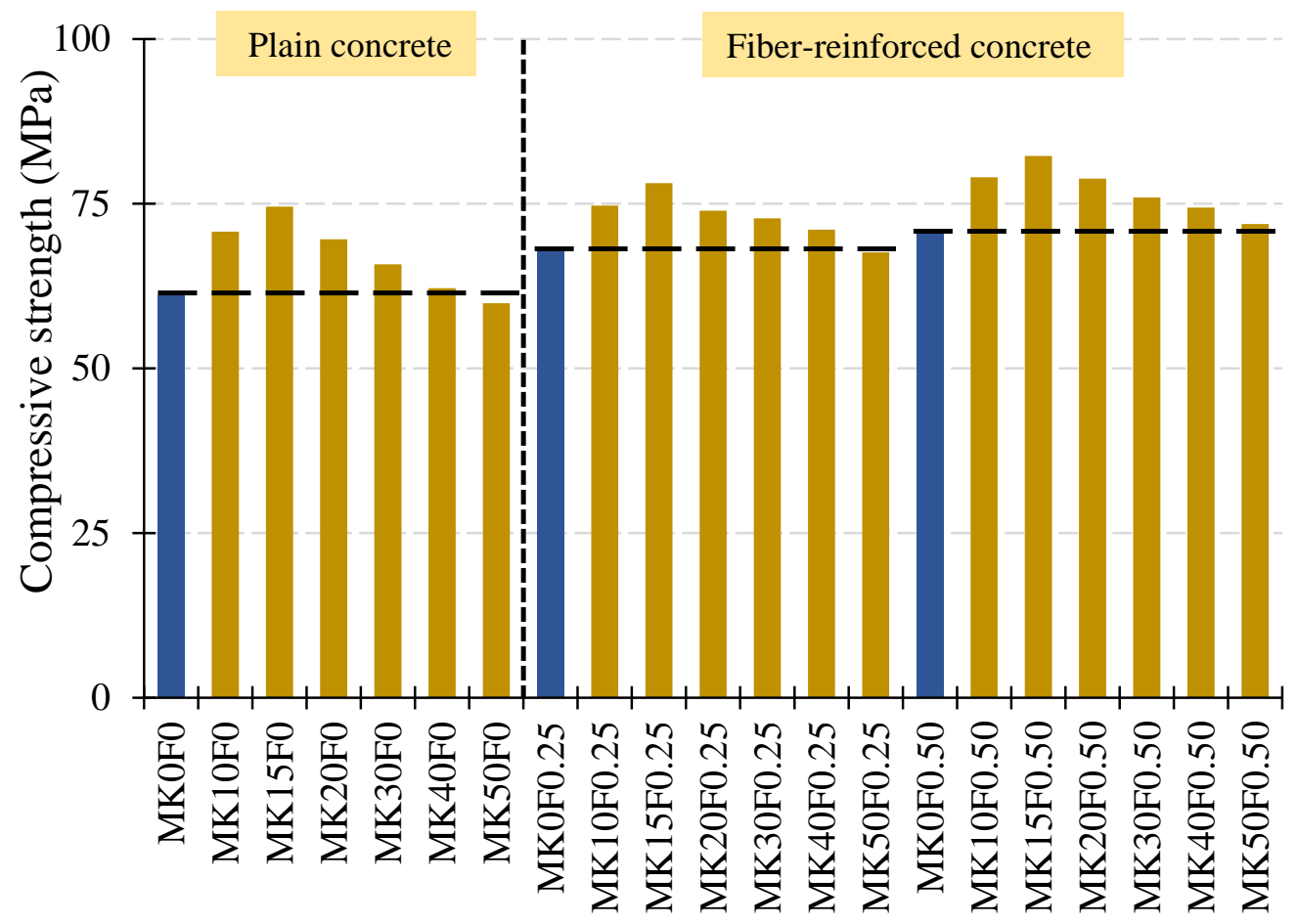

Figure 10. Compressive strength of metakaolin concrete (adapted from El-Din et al. (2017) [148]).

\subsubsection{Effect of Bentonite on Compressive Strength}

Recently, researchers have addressed bentonite as non-kaolin calcined clay and inexpensive SCMs $[21,36,74]$. Although calcined kaolinite is an excellent SCM, removing impurities during the manufacturing of metakaolin consumes energy, increasing the cost of the SCM. Thus, the research tried to develop non-kaolin calcined clays to minimize the purification process of metakaolin as an SCM. Many studies have concluded that raw bentonite concrete has lower early-stage compressive strength, but the later age strength of bentonite samples is quite appreciable [4] (Figure 11). In this context, Masood et al. (2020) [153] reported that the addition of bentonite results in the densification of the matrix and enhances the microstructure of the concrete. In another paper, Targan et al. (2002) [56] showed that as curing time expanded, bentonite decreased compressive strength compared to the normal concrete. Furthermore, Ahmad et al. (2011) [5] reported that the compressive strength decreased with the increased percentage of bentonite as cement replacement at all ages. However, in this context, Liu et al. (2020) [111] reported that the addition of different types of bentonite (sodium bentonite (Na-bent), calcium bentonite (Ca-bent), and magnesium bentonite (Mg-bent)) causes a considerable increase in the compressive strength. Among these bentonite types, sodium bentonite has the most influence on the concrete compressive strength. These conflicting results regarding raw bentonite need to be further studied in future works. Different methods of bentonite production (heating temperature) affect the integration of previous research. In this field, Memon et al. (2012) [4] concluded that to achieve higher compressive strength, bentonite should be heated at $200{ }^{\circ} \mathrm{C}$. Bentonite-containing beam also has a high ductility ratio (the area under the curve), which is a vital feature to dissipate energy in case of earthquakes [52] (Figure 12). In this field, Trümer et al. (2019) [154] experimentally studied the mechanical properties of calcined bentonite as a reactive pozzolan when heat treated at temperatures about $900{ }^{\circ} \mathrm{C}$. They found that using calcined bentonite causes a reduction in early-age strength of concrete mixtures due to the slow hydration rate, while complete $100 \%$ compensation was observed for the long-term strength of the calcined bentonite-containing concrete mixture. In this field, Laidani et al. (2020) [155] determined the effect of calcined bentonite on the fresh and mechanical properties of self-compacting concrete. They reported that for 3-day strength, calcined bentonite reduces the concrete compressive strength for all dosages, while the 
addition of calcined bentonite causes higher 28-day concrete compressive strength with the optimum dosage of $15 \%$. A reduction was observed beyond this replacement rate. Moreover, Xie et al. (2019) [156] reported that the dry density of concrete specimens affects the results, so that compressive strength decreased at lower density $\left(<400 \mathrm{~kg} / \mathrm{m}^{3}\right) \mathrm{but} \mathrm{im-}$ proved at higher density with the increase of pre-saturated bentonite. Similarly, Yang et al. (2019) [157] showed that using $4 \%$ and $8 \%$ bentonite (natural sodium bentonites) results in $18.1 \%$ and $61.5 \%$ increase in compressive strength of mortar. Overall, the previous results indicate that age of the bentonite-based concrete specimens, bentonite dosage, bentonite calcination (treatment), and specimen density have considerable impact on the mechanical properties of bentonite-based concrete specimens.

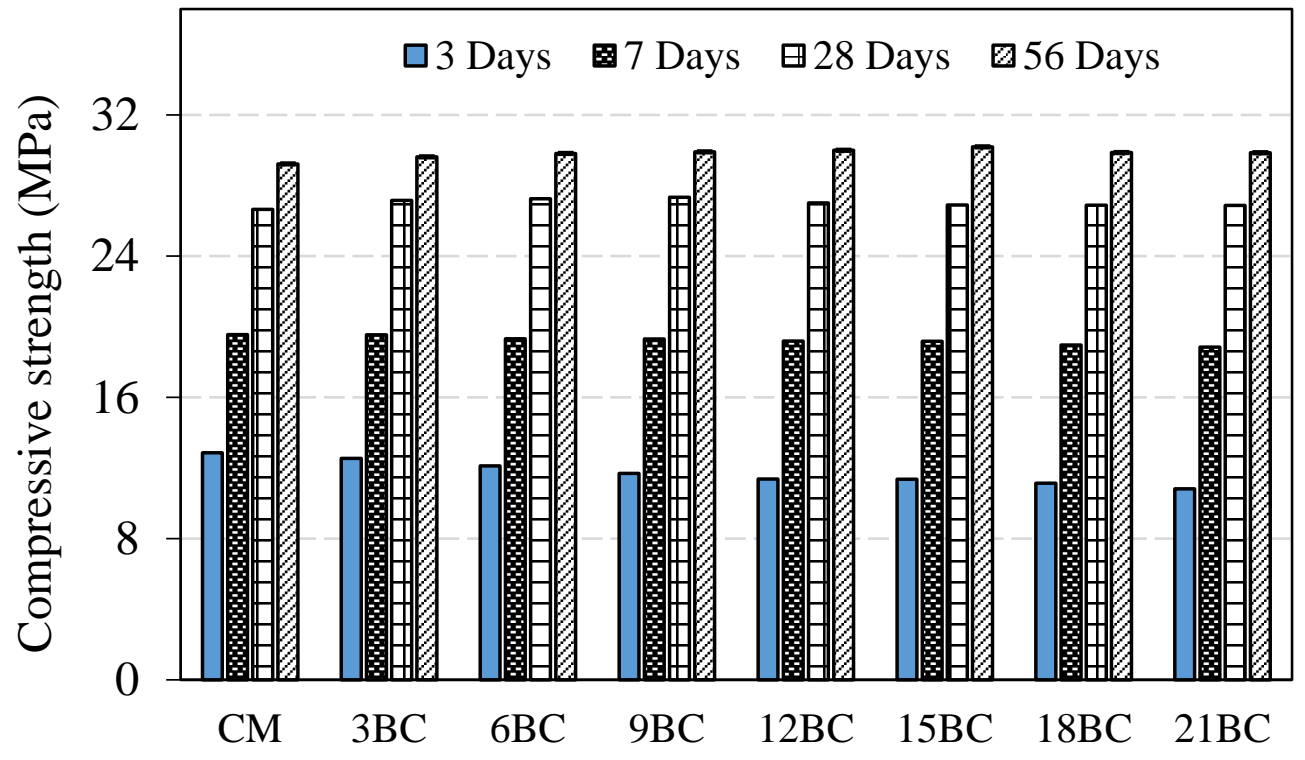

Figure 11. Effect of bentonite on the concrete compressive strength (values mentioned after "BC" correspond to the bentonite percent by weight of cement (adapted from Memon et al. (2012) [4])).

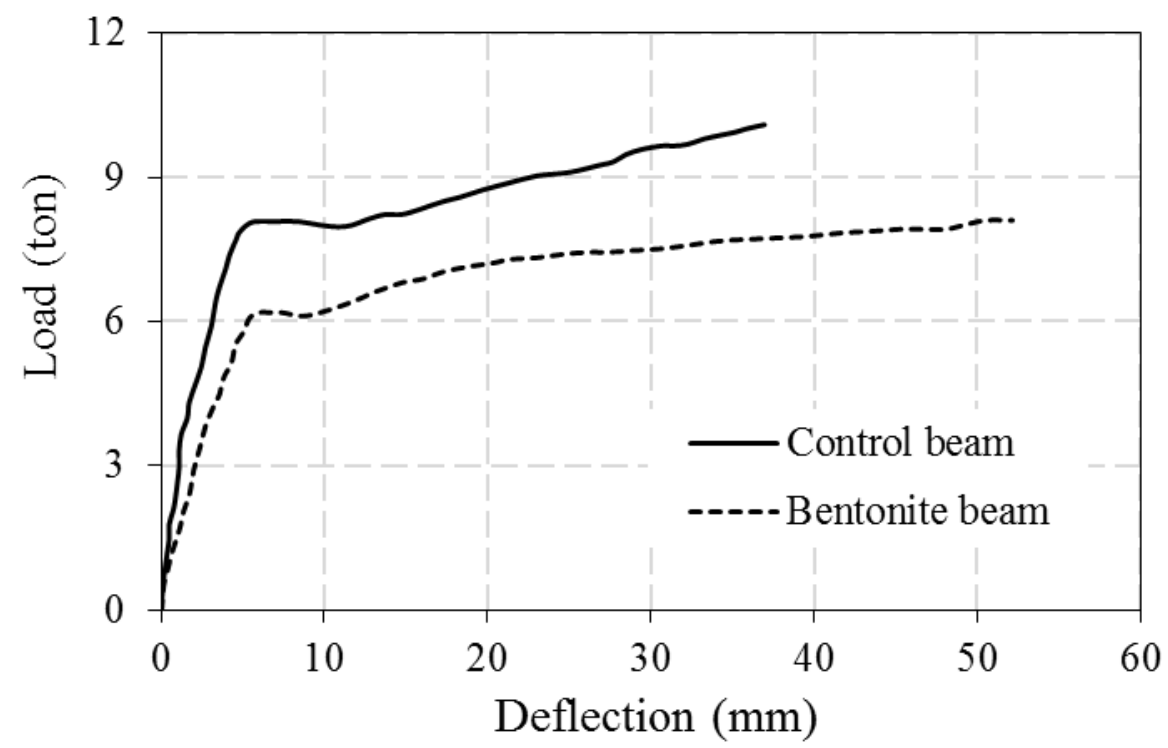

Figure 12. Effect of bentonite on the ductility of RC beam (bentonite beam contains $25 \%$ bentonite (of control mixture) and 75\% ordinary Portland cement; control beam contains 100\% ordinary Portland cement, adapted from Mirza et al. (2009) [52]). 


\subsubsection{Effect of Nano-Clay (NC) on Compressive Strength}

Nano-clay (NC) is a new generation of processed clay for achieving high-performance cement nano-composites [158]. Nano-clay not only reduces the pore size and porosity of the cement mixture but also improves the strength [159] (Figure 13). Nano-clay and calcined nano-clay $(\mathrm{CNC})$ increase the compressive strength of cement at low content $(1 \%$ to $3 \%$ ). Calcined nano-clay is more effective in increasing concrete compressive strength than nano-clay. There are three mechanisms attributed to the improvement of strength in nano-clay containing pastes, including: (1) nano-clays can act as a filler due to their nano-sized particles $[160,161]$; (2) the high amount of $\mathrm{SiO}_{2}$ in nano-clay on its ultra-thin surface can increase the rate of C-S-H [162,163]; and (3) the swelling of tubular nanoclay due to entrapment of water within its layers, which results in expansion of the clay and then an enhanced filling effect in the capillary pores [161]. In this context, Zhang et al. (2021) [164] determined the influence of nano-metakaolinite clay on the mechanical characteristics of cement-based materials. They found that nano-metakaolinite clay efficiently fills the internal pores of cement-based materials and enhances the pore structure by considerably increasing the micro-scale compactness. They reported that the dispersion technique of nano-clay materials could significantly affect the results. Overall, several previous studies confirmed the positive influence of nano-clay on the concrete compressive strength $[125,158,161,164-168]$. Accordingly, Panda et al. (2019) [169] recommended nanoclays for 3D printable concrete. They found that the addition of nano-clay improves the early-age strength of 3D printable concrete layers due to its intrinsic properties of flocculation and thixotropy modifier. Moreover, they reported that nano-clay addition reduces the layer deformation owing to a substantial increase in Young's modulus [169]. This study summarizes the strength efficiency of different types of clay in Figure 14. Results show that metakaolin has the highest efficiency among other types of clay. Moreover, nano-clay has comparable results compared to metakaolin for lower dosages (less than $4 \%$ ), while higher dosages of nano-clays have a significantly lower strength efficiency factor than metakaolin. Bentonite has the lowest considerable strength efficiency factor among clay types.

\subsubsection{Effect of Organo-Clay (OC) on Compressive Strength}

Smectites (especially montmorillonite) have been widely used to produce organoclays [77]. Porosity and capillary pore size significantly affect the strength of cement-based material. Organo-modified clay, such as organo-modified montmorillonite (OMMT), can be used as fillers and reinforcement to reduce cement or concrete porosity (Figure 15). The compressive strength of OMMT cement mortar increases initially and then decreases dramatically by increasing OMMT dosage [80,81]. The optimal dosage of OMMT for cement mortars should be less than $0.25 \%$ when $\mathrm{w} / \mathrm{c}=0.4,0.25-0.5 \%$ when $\mathrm{w} / \mathrm{c}=0.485$, and $0.5-0.75 \%$ when $\mathrm{w} / \mathrm{c}=0.55$ [80]. Kuo et al. (2011) [81] reported that the adequate dosages of OMMT particles to give higher compressive strength are around $0.25 \%$ and $1 \%$ when $\mathrm{w} / \mathrm{c}$ ratios are 0.485 and 0.6 , respectively. 


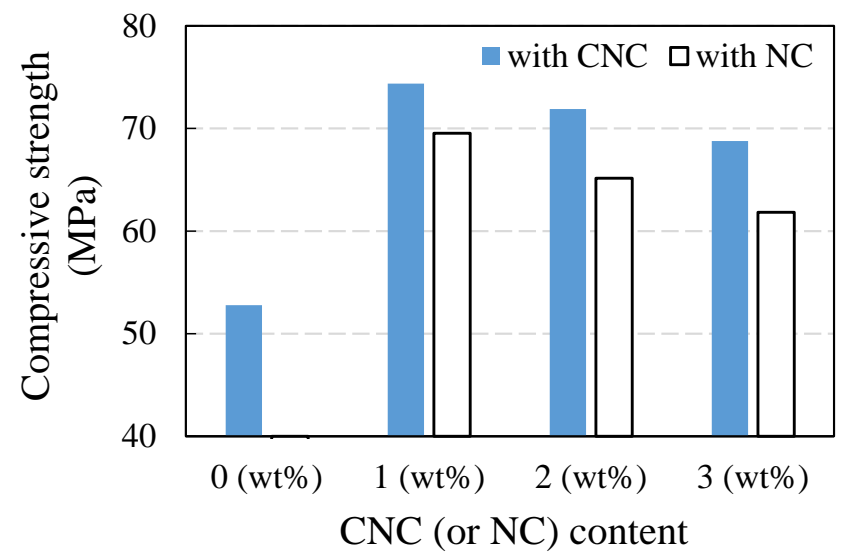

(a) $\mathrm{NC}=$ nano-clay (natural montmorillonite modified with a quaternary ammonium salt); $\mathrm{CNC}=$ calcined nano-clay.

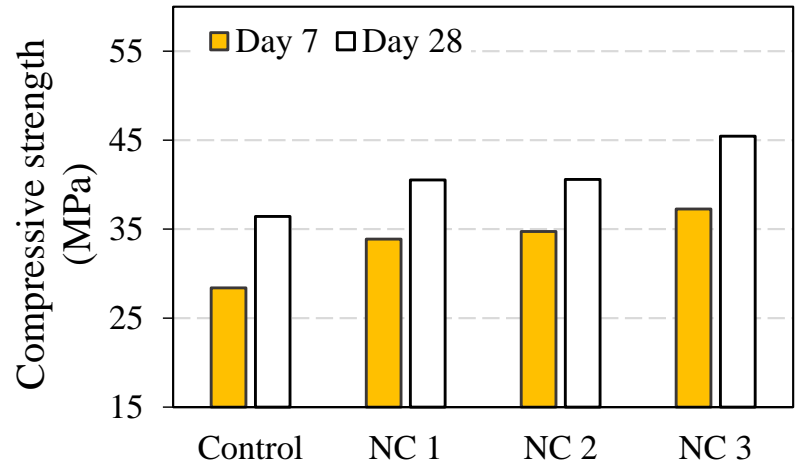

(b) NC is a halloysite nano-clay which was chemically similar to kaolin, with a linear formula of $\mathrm{Al}_{2} \mathrm{Si}_{2} \mathrm{O}_{5}(\mathrm{OH})_{4} \cdot 2 \mathrm{H}_{2} \mathrm{O} ; \mathrm{NC} 1, \mathrm{NC} 2$, and $\mathrm{NC} 3$ contain $1 \%, 2 \%$, and $3 \%$ mass of nano-clay.

Figure 13. Influence of nano-clay and calcined nano-clay on the concrete compressive strength: (a) adapted from Hakamy et al. (2015) [158]; (b) adapted from Farzadnia et al. (2013) [161].

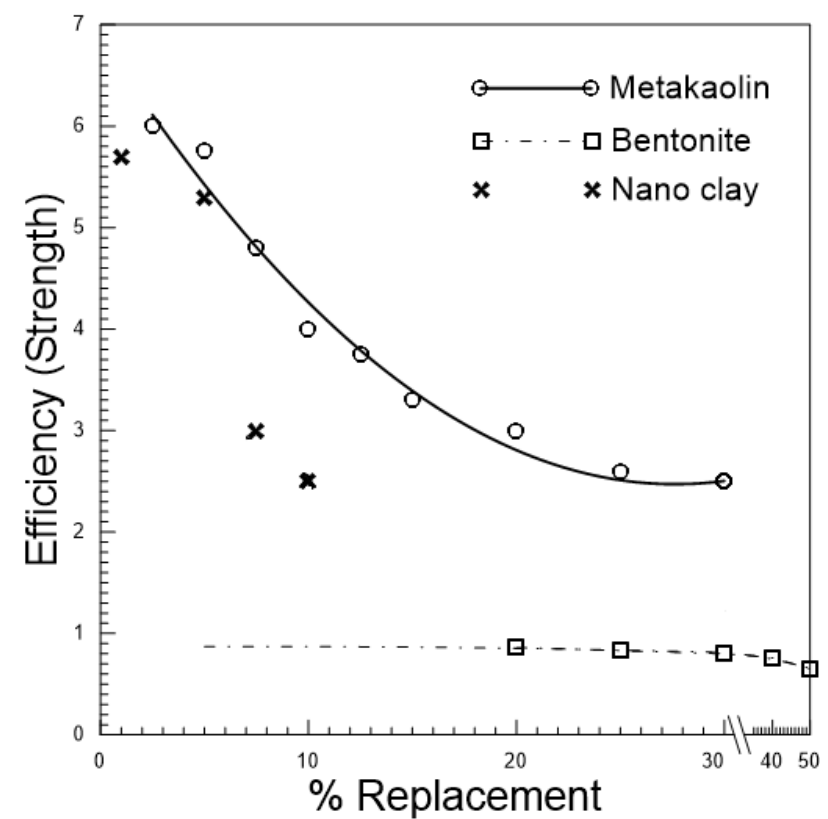

Figure 14. Strength efficiency of concrete for different replacements of clay additives. (Produced entirely by the authors through analyzing the experimental database reported by the literature [5,52]). 


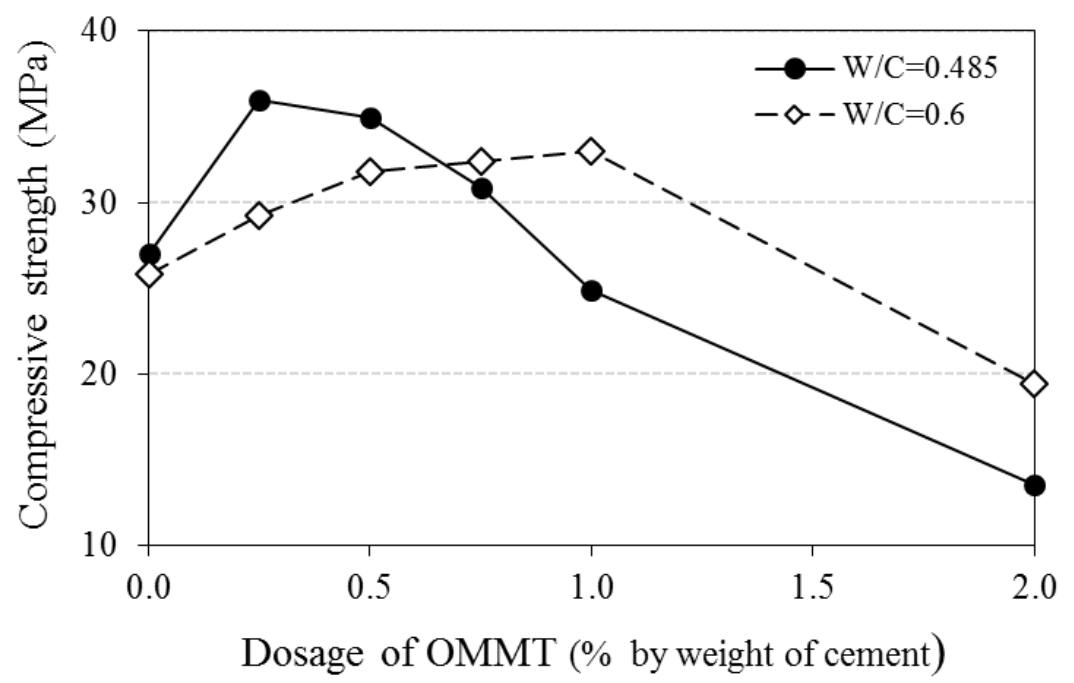

Figure 15. Influence of organo-modified montmorillonite (OMMT) on the compressive strength of cement mortars reinforced with different dosages (adapted from Kuo et al. (2011) [81]).

\subsection{Bond Strength}

Previous studies reported that concrete composition significantly affects the bond strength between reinforcing bar (rebar) and surrounding concrete [170,171]. A few researchers have studied the effect of clays on the bond strength of reinforcing bars in the surrounding concrete. Karahan et al. (2012) [172] studied the fresh, mechanical, and transport properties of expanded shale aggregate self-consolidating lightweight concrete (SCLC) containing metakaolin. Their results show that metakaolin content has no positive effect on all strength properties, including a bond of SCLC mixtures. Results reported by Sancak et al. (2017) [173] showed a similar trend. They reported that for non-corroded pullout specimens, the mixture without metakaolin showed the highest normalized bond strength among the other non-corroded specimens. However, Güneyisi et al. (2014) [174] reported that metakaolin has a positive effect on the interfacial transition zone (ITZ) and also bond strength. Similarly, El-Din et al. (2017) [148] experimentally studied the effect of metakaolin on bond strength of $10 \mathrm{~mm}$ steel rebar embedded in plain and fiber-reinforced concrete specimens. They found that metakaolin content has a considerable influence on the results. For instance, they reported that $15 \%$ metakaolin causes a $7.73 \%$ increase in the bond strength, while a considerable decrease was observed for cement replacement for more than $15 \%$. These bond improvements are about $16.9 \%$ and $21.83 \%$ for $0.25 \%$ and $0.50 \%$ steel fiber volume fractions, respectively [148]. In this field, Albidah et al. (2020) [66] experimentally examined the bond strength of GFRP and steel rebars embedded in metakaolin-based geopolymer concrete. They reported that normalized bond strength metakaolin-based geopolymer concrete is generally lower than that of normal concrete for steel and GFRP rebars. Similarly, Zhang et al. (2015) [175] and Fan et al. (2016) [176] found that the addition of nano-kaolinite can improve the bonding behavior of concrete and steel bars and reduce the stiffness of concrete specimens. It seems that additional experiments are necessary to determine the effect of different types of clay on rebar-concrete interaction in reinforced concrete members. In this field, Zhang et al. (2021) [177] studied the impact of nano-kaolinite clay on the interfacial properties between rebar and concrete. They found that nano-kaolinite clay ( $5 \%$ nano-clay) enhanced the chloride resistivity and rebar-concrete bond strength. Another interface in the reinforced concrete structures is the interaction between fibers and surrounding concrete. In this context, Banthia and Yan (1996) [178] found that the bond strength of deformed steel fibers embedded in cement paste containing $10 \%$ metakaolin (by weight of cement) is higher as compared to the mixture containing silica fume. Similarly, Lee et al. (2012) [179] reported that the addition of metakaolin and silica fume efficiently improves the polyvinyl alcohol fiber-cement mortar bond strength 
by an optimum dosage of $10 \%$ for metakaolin. The literature confirmed these promising results for metakaolin and nano-clay with specific dosages [180,181].

\section{Effect of Clay on the Durability of Concrete}

According to the American Concrete Institute (ACI) Committee 201 [182], the durability of hydraulic-cement concrete is defined as its capability to resist weathering action, chemical attack, abrasion, and different deterioration processes. Tang et al. (2015) [183] classified the durability problems in concrete into the alkali-aggregate reaction, sulphate attack, steel corrosion, and freeze-thaw. The effect of adding clay-based materials (raw, calcined, and nano-clays) in concrete on each of these durability problems are discussed in the following subsections.

\subsection{Effect of Clay on the Alkali-Aggregate Reaction (AAR) in Concrete}

This phenomenon (AAR) is a reaction between the $\mathrm{OH}$-ion (hydroxyl groups) associated with the alkalies $\left(\mathrm{Na}_{2} \mathrm{O}\right.$ and $\left.\mathrm{K}_{2} \mathrm{O}\right)$ from the cement and siliceous constituent in the aggregate as an active chemical [182]. Alkali-carbonate reaction (ACR) and alkali-silica reaction (ASR) are the two types of attacks of AAR. The high $\mathrm{pH}$, moisture, and reactive materials in aggregates such as silica are the three essential conditions which generate this reaction in concrete. The use of blended cement with enough pozzolanic materials such as fly ash, silica fume, slag, rice husk ash, and natural pozzolans is an effective way of eliminating the attack of AAR [183-185]. By thermal treatment of clays (like metakaolin), the crystal structure is destroyed and generates an amorphous or disordered aluminosilicate structure, obtaining pozzolanic material $[184,186]$. This heat treatment increases resistance to the alkali-silica reaction $[187,188]$. By utilizing metakaolin as a replacement for cement, mechanisms of forming a supplementary calcium aluminate and calcium aluminosilicate hydrate through reaction with the $\mathrm{Ca}(\mathrm{OH})_{2}$ of Portland cement hydration control the ASR attack [189]. Incorporation of $20 \%$ metakaolin was found to significantly reduce the long-term $\mathrm{OH}^{-}, \mathrm{Na}^{+}$, and $\mathrm{K}^{+}$ion concentrations in pore solutions (reduction in the $\mathrm{pH}$ and the alkalinity of pore solutions) and also the reduction in expansion of the concrete prisms (Figure 16) [190]. Moreover, as a critical parameter for controlling ASR, the high aluminum content in metakaolin has been illustrated to contribute to ASR reduction [190-192]. In this context, Trümer and Ludwig (2015) [193] experimentally studied the effect of using concrete made with calcined clay-blended cement on the ASR evaluation. They used various types of clays (kaolinite, montmorillonite, and illite) to obtain calcined clays. They found that calcination of kaolinite and montmorillonite significantly reduces the expansion of the concrete. Finer porosity inhibiting ion transport, a decreased provision of calcium being the main constituent of expanding ASR gel, and the incorporation of alkali ions in the $\mathrm{CSH}$ phases due to lower C/S ratios are the important reasons for the reduction of ASR risk by using calcined clay in concrete or mortar $[193,194]$. In this field, Irshidat et al. (2015) [195] reported that the addition of small amounts of nano-clay reduced the expansion due to the ASR. Decreasing the amount of $\mathrm{CH}$ and nano-reinforcing for obstructing the alkali ions to attack the aggregate particles results from using nano-clay to prevent ASR risk [195]. Despite these findings on metakaolin, a limited study has been performed using other calcined clays of different chemical compositions for ASR mitigation [186]. The chemical composition and mineral phase of calcined clays, which are directly related to the calcination process and temperature, significantly influenced the efficiency of ASR mitigation [186]. 


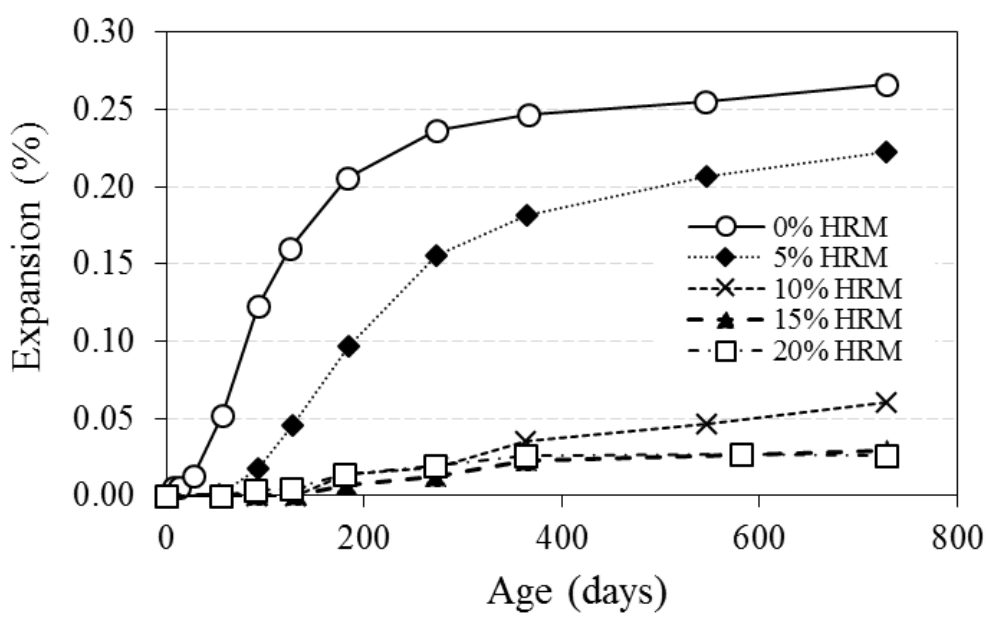

Figure 16. Effect of high-reactivity metakaolin on the alkali-aggregate reaction of concrete containing Spratt aggregate (siliceous limestone) (adapted from Ramlochan et al. (2000) [190]).

\subsection{Effect of Clay on Deterioration Caused by Sulfate Attack}

One of the most common aggressive environmental causes of deterioration of concrete is the sulfate attack. Sulfate ions and moisture are the two crucial factors of sulfate attack. Sulfate attack is due to the chemical reaction of sulfate ions with calcium hydroxide and calcium aluminate hydrate, which results in the formation of gypsum and ettringite. The damage caused by the formation of gypsum and ettringite crystals involves expansion, cracking, deterioration, and disruption of concrete structures. Metakaolin replacement of cement enhances the sulfate resistance of concrete. Many researchers have studied the effect of calcined kaolinite (metakaolin) on the sulphate risk of concrete [41,196-199]. The sulfate resistance of metakaolin concrete increased with increasing the metakaolin replacement level (Figure 17). By consuming $\mathrm{Ca}(\mathrm{OH})_{2}$, metakaolin significantly affects the durability of concrete and mortar exposed to a sulfate environment [41,197].

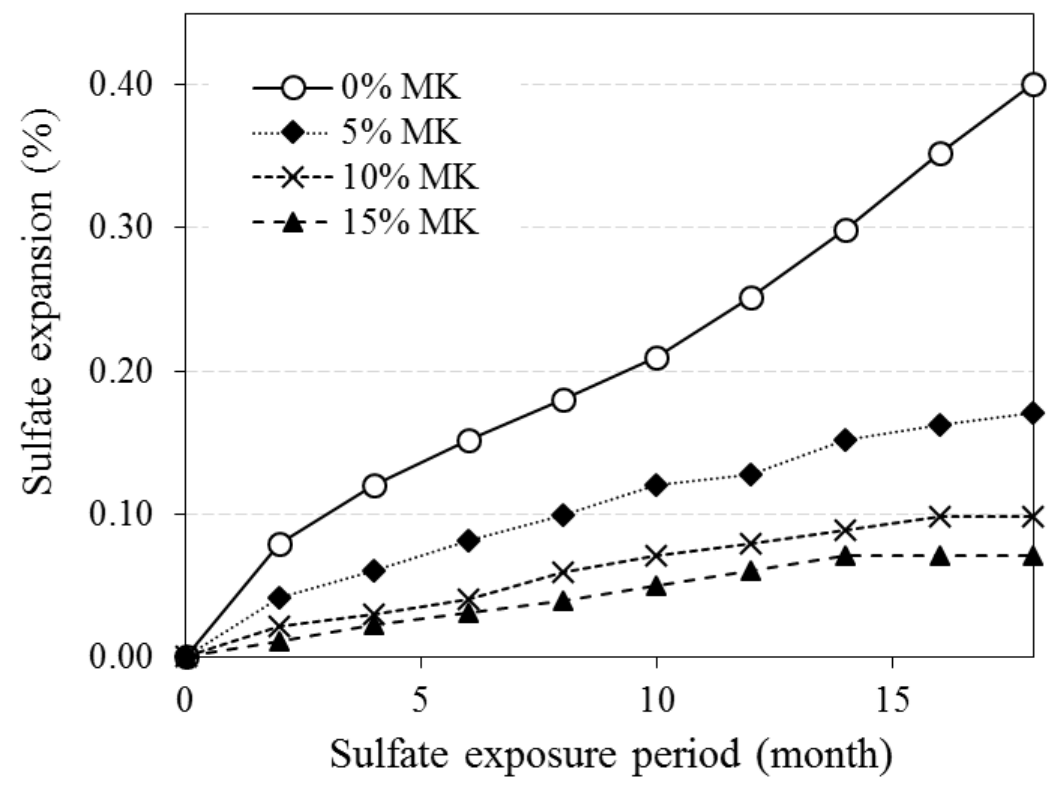

Figure 17. Effect of metakaolin replacement level on the variation of sulfate expansion with sulfate exposure period at $\mathrm{w} / \mathrm{b}$ ratio of 0.5 (adapted from Al-Akhras (2006) [41]).

\subsection{Effect of Clay on the Steel Corrosion}

An anodic oxidation site, a cathodic reduction site, an electrical connection between the anode and cathode to transfer electrons, an electrolytic environment to transfer ions and 
complete the circuit, and the availability of reactants at the site of corrosion such as $\mathrm{CO}_{2}$, $\mathrm{Cl}^{-}$, and $\mathrm{H}_{2} \mathrm{O}$ are the components necessary for corrosion of embedded steel reinforcement [200]. Concrete confinement surrounding the steel reinforcing bar provides a passive state with a high $\mathrm{pH}$ environment, preventing depassivation. Carbonation and chloride ion concentration are the two important reasons for initiating the rebar depassivation or corrosion. Carbonation of concrete can happen due to the diffusion of carbon dioxide from the environment sources through the concrete pores, decreasing the concrete $\mathrm{pH}$. Lower $\mathrm{pH}$ accelerates the initiation of reinforcement corrosion and results in deterioration of concrete durability [200]. Use of seawater for mixing water, dredged aggregate, aggregate washed with seawater, and chloride-containing admixtures, and environmental factors are the internal or external sources of penetrating chlorides into concrete [200]. Water and oxygen help the chloride ions for initiating the corrosion of embedded steel rebar [201]. Thus, as concrete is a porous composite material, the penetration of aggressive ions into concrete depends mainly on the microstructure and the chemistry of the mixture [202]. The existence of metakaolin changes the mix design and affects concrete corrosion resistance [201-205]. When chloride concentration increases, the corrosion current density increases, and concrete become more vulnerable to corrosion [201]. However, it has been deduced that metakaolin concrete is efficient in preventing the active corrosion of concrete, even at severe chloride contamination levels (Figure 18).

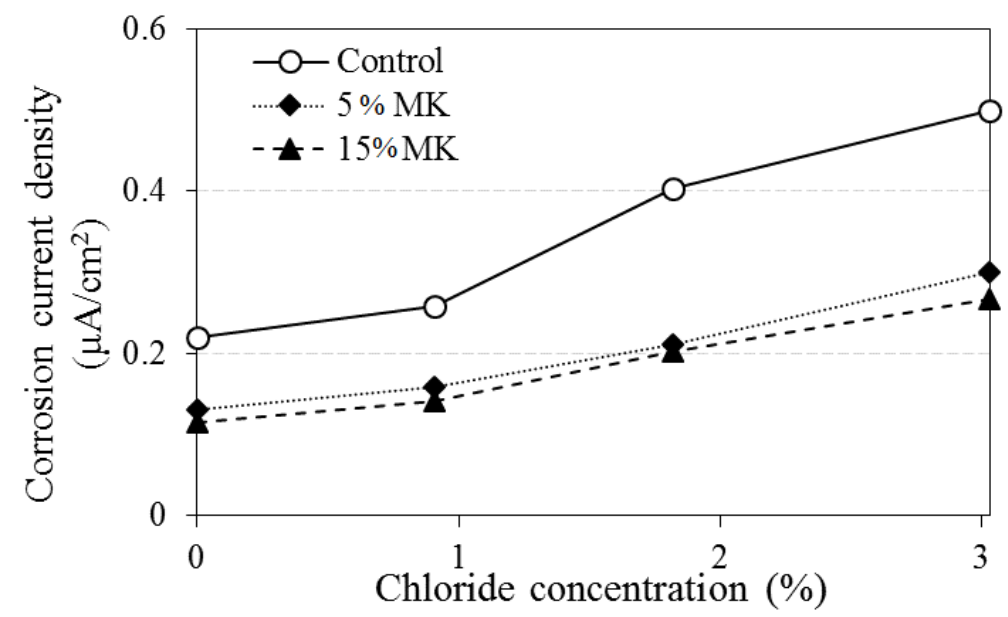

(a)

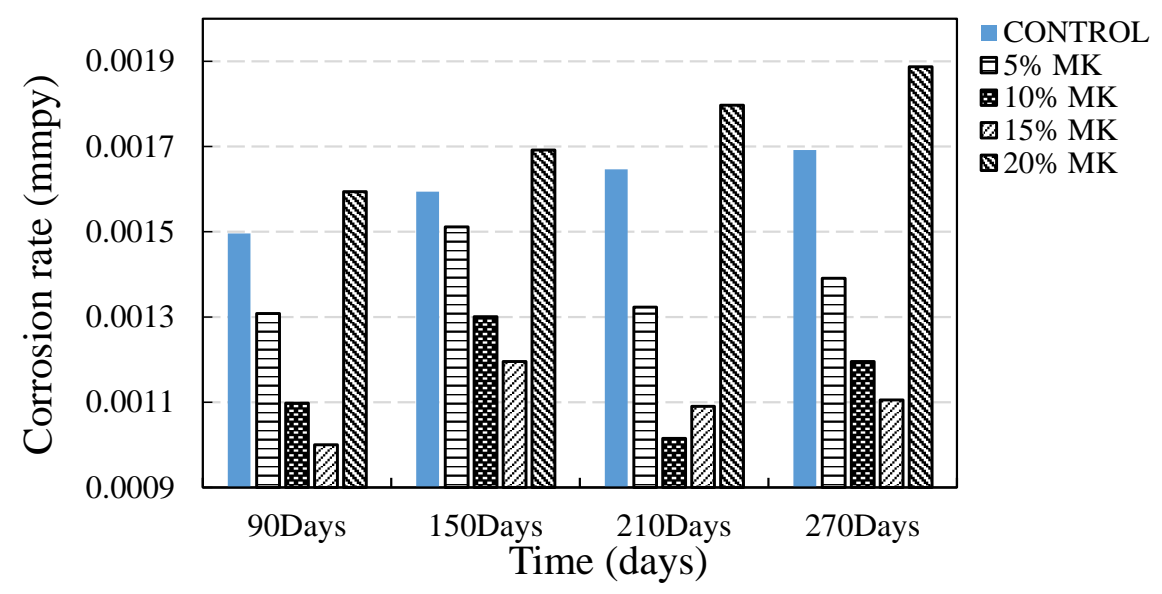

(b)

Figure 18. Effect of metakaolin on corrosion resistance of concrete: (a) change of the corrosion current density with the change in levels of chloride contamination (adapted from Güneyisi et al. (2013) [201]); (b) weight loss measurement (adapted from Parande et al. (2008) [206], mmpy = millimeter per year). 


\subsection{Effect of Clay on the Freeze-Thaw}

The presence of water in low-permeable concretes exposed to severe winter conditions such as freezing-thawing causes significant deterioration, including swelling, surface scaling, spalling, aggregate exposing, cracking, and broken-off concrete [176,183]. The resistance of concrete to freezing and thawing was determined by accelerating the freezing and thawing cycle test until 300 cycles, according to the standard test method for resistance of concrete to rapid freezing and thawing, KS F 2456 [207]. The addition of metakaolin enhances the resistance of concrete to freezing and thawing [208-210]. Experimental works related to the weight change and pulse velocity at each cycle evaluate the effect of freezingthawing cycles on the performance of concrete. The metakaolin concrete exhibits a lower weight gain or pulse velocity reduction compared to the ordinary concrete (Figure 19). Lower weight gains result in less water absorption and the existence of fewer internal cracks in concrete.

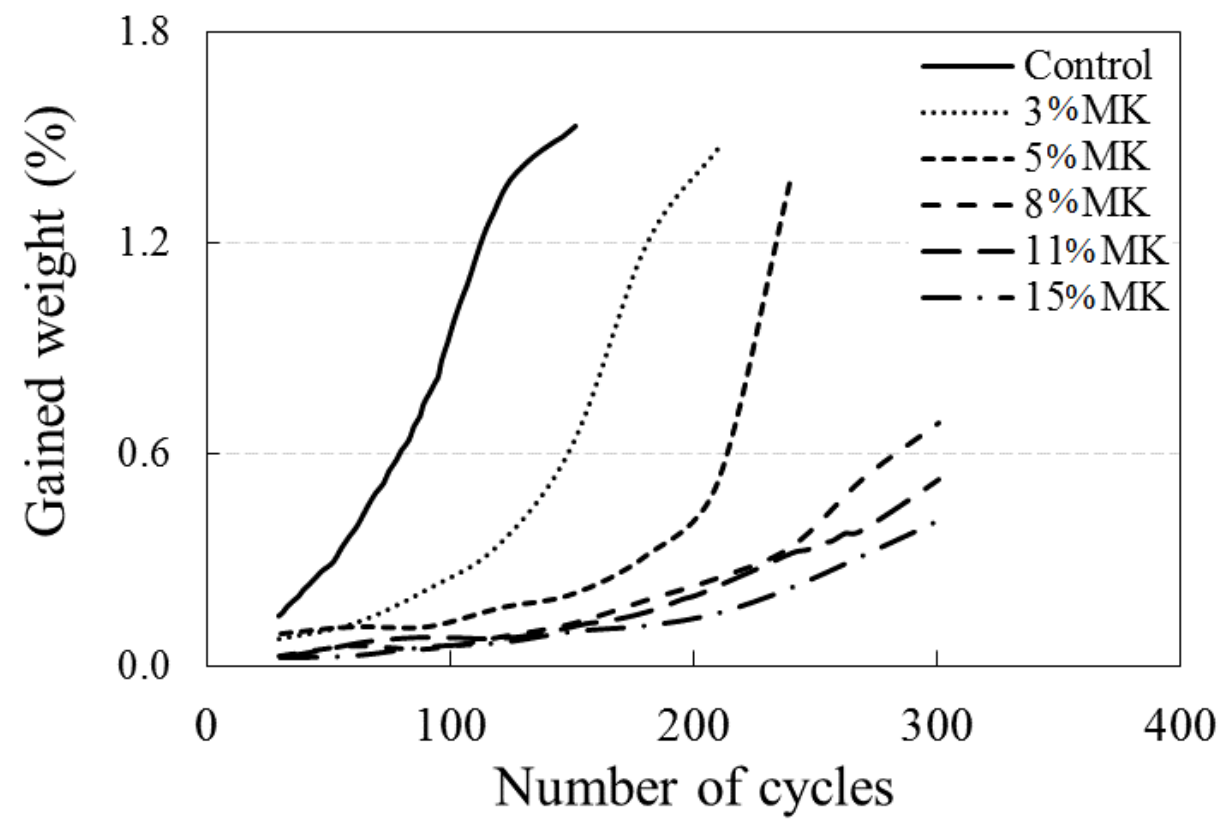

Figure 19. Percentage of weight gained of freezing and thawing specimens for all tested SCC (adapted from Hassan et al. (2012) [210], the amount of moisture absorbed due to cracking caused by expansion of the cement paste).

Since concrete is a porous material, the freeze-thaw resistance of concrete depends mainly on the structure of the material, such as porosity. Concrete with low porosity results in a less permeable material that is so resistant when subjected to freeze-thaw action. Thus, the filling and activating effects of nano-clay in concrete can be useful for achieving less permeable and also more durable concrete. With the increase in freeze-thaw cycles, the porosity of concrete increases, which shows that freeze-thaw cycles create a more porous microstructure concrete with high permeability. However, using nano-clay in concrete mixture significantly decreases the concrete porosity, especially in high cycles (Figure 20) [211]. The addition of nano-clay leads to lower permeability [212,213] and also less damage to the surface compared to the control specimen during the freeze/thaw process [176]. 


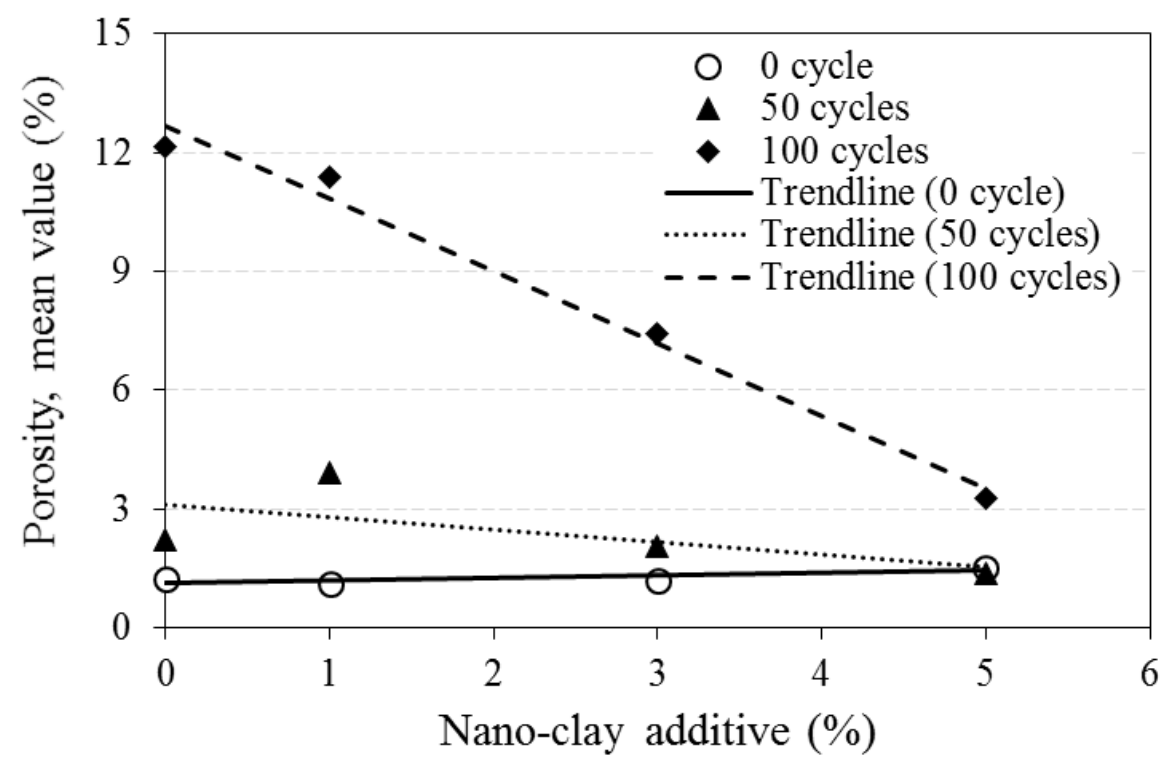

Figure 20. Relations between the average value of porosity and nano-clay additives during the freezing and thawing cycles (adapted from Fan et al. (2015) [211]).

\section{Discussion}

A summary of the references reviewed in this study is illustrated in Table 3. To clarify the future research needs, current research gaps (RG) in clay-based concrete are highlighted by "RG" in Table 3. Bond strength and durability are the two main sections related to clay minerals, which should be considered for future research. As the compressive strength of clay minerals-based concrete was not acceptable enough, there was no interest in more research on durability and bond strength. Most of the previous research has focused on demonstrating the effect of metakaolin on the fresh, hardened, and durability properties of concrete. Although no research gap was found in the field of metakaolin-based concrete (Table 3), more experimental studies are necessary for the sections of flowability and viscosity. Sulfate attack is the only field of study related to nano-clay which needs more concentration in future research. It should be noted that many sections just contain one research paper, which shows additional experimental work should be conducted for approving the reported trends, such as early-age shrinkage and durability of raw clay, fresh properties of metakaolin, and durability and fresh properties of nano-clay. The mark "I" (used in Table 3) shows the positive effect, which means higher flowability, higher viscosity, lower early-age shrinkage, and higher resistance to severe environmental conditions. The term " $U$ " (unsure) is used for cases in which no clear trends have been reported, such as the results of compressive strength for bentonite or organo-clay-based concrete. Fresh property and durability are the sections related to organo-clay, bentonite, and other calcined clays, which need experimental works to fill these current research gaps. As mentioned earlier in the present study, the compressive strength of organo-clay-based concrete is very sensitive to the dosage of organo-clay and also water-to-cement ratio of the mixture so that an optimum dosage cannot be derived from the current references. Thus, the uncertainty of the results is illustrated in the case of organo-clay. Similarly, the mark of unsure is selected for the compressive strength of bentonite-based concrete. The compressive strength of bentonite-based concrete significantly depends on the curing time so that, unlike the 28-day strength, the early-age strength of bentonite-based concrete is lower than free-clay concrete. In recent years, there has been a growing tendency in the literature related to other calcined clays. However, more scientific research is necessary for filling existing needs. Current investigations mostly concentrate on finding different types of calcined clays by changing the temperature and calcination conditions. As finding other alternatives to the existing famous calcined clay (like metakaolin) needs more effort, it seems that this field of study (other calcined clays) is in the early stages. 
Table 3. A summary of references reviewed in this study $(I=$ improve, $D=$ decrease, $U=$ unsure, $R G=$ research gap).

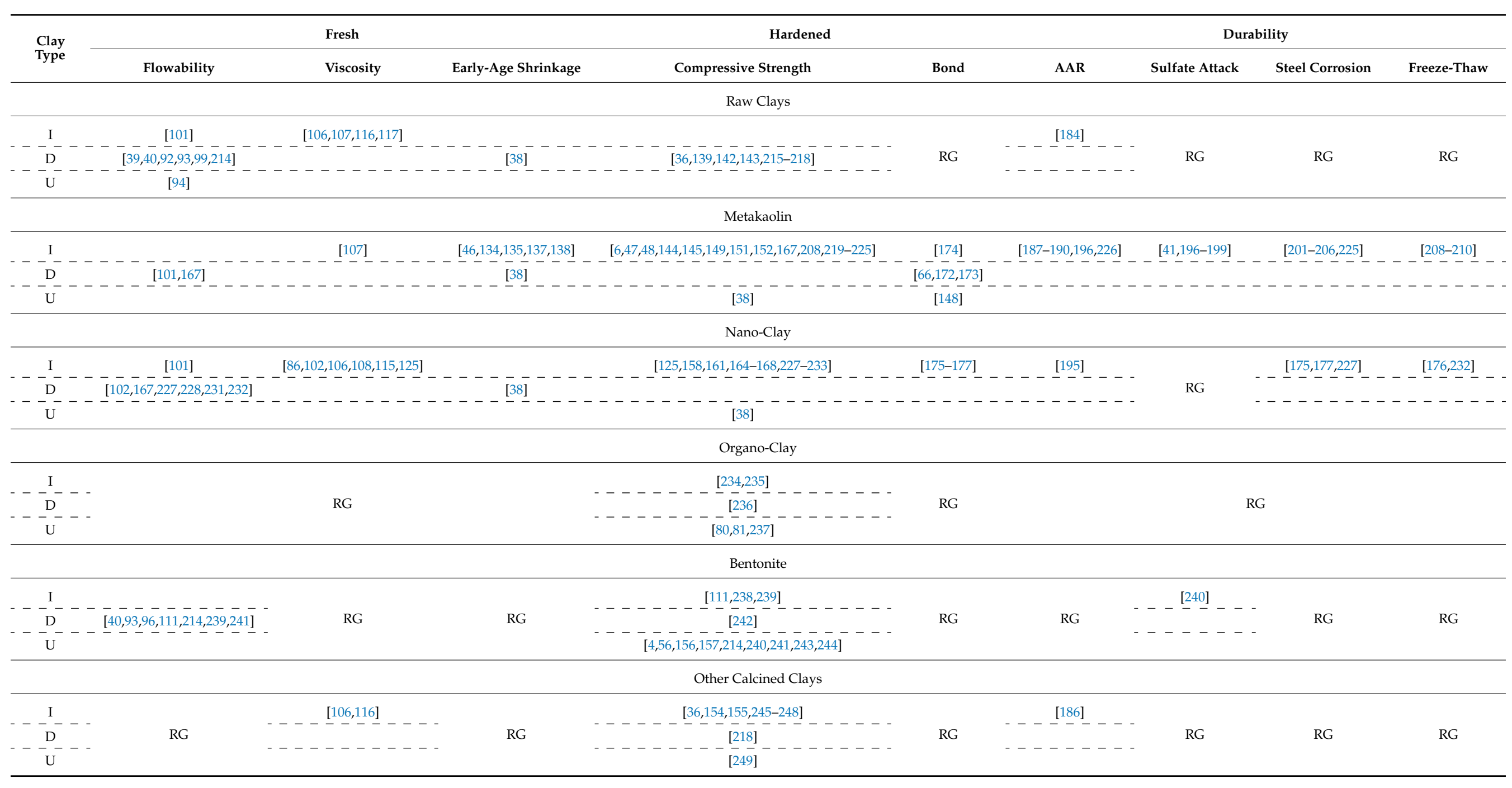


To summarize the existing results (by knowing the current RG), the normalized trend is considered in this section. As Figure 21 shows the positive and negative effects of different types of clays on the fundamental properties of concrete, the rate of increase or decrease has been ignored in this symbolic form. Overall results are considered for the input data of Figure 21, and cases with just one reference have been ignored. It can be deduced from the reviewed references that clay-based concrete has lower flowability and also higher viscosity than normal concrete. This property can be attributed to the high floc strength of clay particles in the mixtures. The high viscosity of clay-based concrete can be a suitable property for use in additive manufacturing or 3D concrete printing. However, the low flowability of clay-based concrete should be controlled by using different types and dosages of superplasticizers. Promising results were reported by the literature to use calcined clay in printable cementitious mortars [250-253]. In 3D concrete printing, the material should have enough viscosity to be properly extruded by the printer and then solid enough to be laid onto the lower layer without collapsing [254]. As shown in Figure 21 and Table 3, no negative or unsure result has been reported for durability properties of clay-based concrete. It shows the very good resistance of clay-based concrete under severe environmental conditions. Uncertainty of other properties is related to the clay types and also few references.

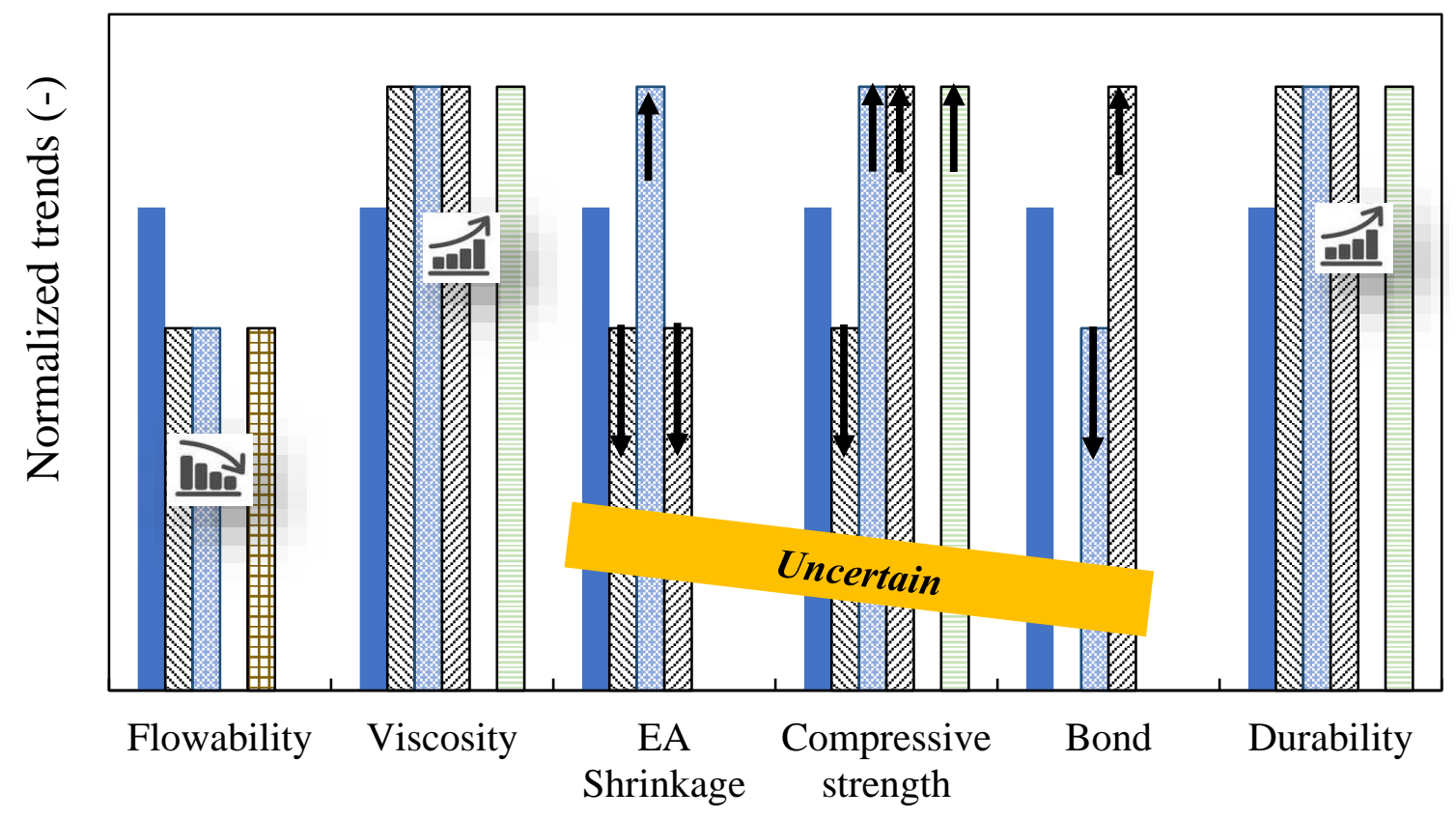

$\square$ No Clay $₫$ Raw $\square$ MK $\square$ Nano-clay $\boxplus$ Bentonite $\boxminus$ Other Calcined Clays

Figure 21. Overall results of the present review study (based on Table 3).

\section{Limitations of the Present Study}

It is worth mentioning that this study mainly intends to highlight the importance and benefits of using clay-based materials as a binder in the concrete mixture to produce sustainable concrete. Due to the large scope of results discussed in the present study, some important topics in this field of research, clay concrete, were ignored, which needs to be considered for future review papers along with performing experimental topics summarized in Table 3. These topics include the thermal characteristics of clay concrete and limestone calcined clay. Additionally, references related to the limestone calcined clay cement $\left(\mathrm{LC}^{3}\right)$ were out of the scope of the present study. A further comprehensive review is essential for future works to prolong the current review. 


\section{Conclusions}

This review reveals that replacing cement with clay in concrete production results in more sustainable concrete with promising durability properties (for all types of clay) and acceptable hardened properties (especially for calcined and nano-sized clays). Claybased concrete (raw and treated) not only has generally no considerable negative impact on concrete properties but also enhances its performance in many aspects. Reviewing available research trends made it possible to draw the following conclusions:

- The mixture with clay replacement has higher thixotropic and yield stress values, which results in the improvement of the shape stability. This characteristic is strongly suitable for using clay-based concrete in 3D printable concrete. This also results in lower shrinkage in the early-age life of the concrete. However, the high floc strength of clay-based concrete causes a reduction in flowability. Using a calcination method and nano-sized clay particles could not solve this issue. Hence, more experimental studies are necessary for future work to propose an efficient way of increasing the flowability of clay-based concrete mixtures. Moreover, there are significant research gaps for organo-clay in this field.

- Mineral clay has an inverse effect on hardened properties, while calcined clay improves the compressive strength of concrete. The calcination or burning process of clay minerals and using nano-clay make a crucial contribution to improving the concrete compressive strength. Regarding bentonite and organo-clay, conflicting results were reported for hardened properties which need to be investigated by future efforts. Moreover, considerable research gaps exist for bond strength (reinforcing bar and fibers).

- $\quad$ Overall results of the section related to durability reveal that all types of clay positively affect the resistance ability of concrete exposed to environmental attack. Results indicate that the dosage of clay replacement should be lower than $15 \%$. However, the present review study shows that major works are still required in this field by future investigations. Current results comprehensively confirmed using metakaolin and nano-clay in concrete exposed to a harsh environment.

It should be noted that this review study has revealed the scientific gaps necessary in the field of clay-based concrete. Solving these research needs by future studies can be an essential improvement for considering specific regulations in the design codes for using clay-based materials in construction. Specifications of design codes can consist of information regarding the clay dosage in concrete production and the optimum types of clay (minerals or modified).

Author Contributions: The contribution is the result of the joint work of the authors. In particular: conceptualization, S.S.M.; methodology, S.S.M., C.B.; validation, S.S.M., C.O.-P.; formal analysis, S.S.M., C.B.; investigation, S.S.M., C.B.; data curation, S.S.M.; writing-original draft preparation, S.S.M., C.B.; writing-review and editing, S.S.M., C.B., C.O.-P.; visualization, S.S.M.; supervision, C.O.-P. All authors have read and agreed to the published version of the manuscript.

Funding: This research received no external funding.

Data Availability Statement: The data are contained within the article.

Conflicts of Interest: The authors declare no conflict of interest.

\section{References}

1. Kouakou, C.; Morel, J.-C. Strength and elasto-plastic properties of non-industrial building materials manufactured with clay as a natural binder. Appl. Clay Sci. 2009, 44, 27-34. [CrossRef]

2. Berriel, S.S.; Favier, A.; Domínguez, E.R.; Machado, I.S.; Heierli, U.; Scrivener, K.; Hernández, F.M.; Habert, G. Assessing the environmental and economic potential of Limestone Calcined Clay Cement in Cuba. J. Clean. Prod. 2016, 124, 361-369. [CrossRef]

3. Andrew, R.M. Global $\mathrm{CO}_{2}$ emissions from cement production. Earth Syst. Sci. Data 2018, 10, 195-217. [CrossRef]

4. Memon, S.A.; Arsalan, R.; Khan, S.; Lo, T.Y. Utilization of Pakistani bentonite as partial replacement of cement in concrete. Constr. Build. Mater. 2012, 30, 237-242. [CrossRef] 
5. Ahmad, S.; Barbhuiya, S.; Elahi, A.; Iqbal, J. Effect of Pakistani bentonite on properties of mortar and concrete. Clay Miner. 2011, 46, 85-92. [CrossRef]

6. Tongbo, S.; Bin, W.; Lijun, Z.; Zhifeng, C. Meta-kaolin for high performance concrete. In Calcined Clays for Sustainable Concrete; Springer: Berlin/Heidelberg, Germany, 2015; pp. 467-477.

7. Scrivener, K.L. Options for the future of cement. Indian Concr. J. 2014, 88, 11-21.

8. Duxson, P.; Provis, J.L. Low $\mathrm{CO}_{2}$ concrete: Are we making any progress? In BEDP Environment Design Guide; PRO24, 24:1-7; Australian Institute of Architects: Melbourne, Australia, 2008.

9. Schneider, M.; Romer, M.; Tschudin, M.; Bolio, H. Sustainable cement production-Present and future. Cem. Concr. Res. 2011, 41, 642-650. [CrossRef]

10. Kajaste, R.; Hurme, M. Cement industry greenhouse gas emissions-Management options and abatement cost. J. Clean. Prod. 2016, 112, 4041-4052. [CrossRef]

11. Deja, J.; Uliasz-Bochenczyk, A.; Mokrzycki, E. $\mathrm{CO}_{2}$ emissions from Polish cement industry. Int. J. Greenh. Gas. Control. 2010, 4 , 583-588. [CrossRef]

12. Flatt, R.J.; Roussel, N.; Cheeseman, C.R. Concrete: An eco material that needs to be improved. J. Eur. Ceram. Soc. 2012, 32, 2787-2798. [CrossRef]

13. Narang, K.C. Portland and blended cement. In Proceedings of the Ninth International Congress on the Chemistry of Cement, National Council for Cement and Building Materials, New Delhi, India, 1992; pp. 213-257. Available online: https://iccc-online. org/fileadmin/gruppen/iccc/ICCC09_1992.pdf (accessed on 27 September 2021).

14. Alujas, A.; Fernández, R.; Quintana, R.; Scrivener, K.L.; Martirena, F. Pozzolanic reactivity of low grade kaolinitic clays: Influence of calcination temperature and impact of calcination products on OPC hydration. Appl. Clay Sci. 2015, 108, 94-101. [CrossRef]

15. Teklay, A.; Yin, C.; Rosendahl, L. Flash calcination of kaolinite rich clay and impact of process conditions on the quality of the calcines: A way to reduce $\mathrm{CO}_{2}$ footprint from cement industry. Appl. Energy 2016, 162, 1218-1224. [CrossRef]

16. Damtoft, J.S.; Lukasik, J.; Herfort, D.; Sorrentino, D.; Gartner, E.M. Sustainable development and climate change initiatives. Cem. Concr. Res. 2008, 38, 115-127. [CrossRef]

17. Olotuah, A. Recourse to earth for low-cost housing in Nigeria. Build. Environ. 2002, 37, 123-129. [CrossRef]

18. Galán-Marín, C.; Rivera-Gómez, C.; Petric, J. Clay-based composite stabilized with natural polymer and fibre. Constr. Build. Mater. 2010, 24, 1462-1468. [CrossRef]

19. Tironi, A.; Trezza, M.A.; Scian, A.N.; Irassar, E.F. Kaolinitic calcined clays: Factors affecting its performance as pozzolans. Constr Build. Mater. 2012, 28, 276-281. [CrossRef]

20. Scrivener, K.; Martirena, F.; Bishnoi, S.; Maity, S. Calcined clay limestone cements (LC3). Cem. Concr. Res. 2018, 114, 49-56. [CrossRef]

21. Fernandez, R.; Martirena, F.; Scrivener, K.L. The origin of the pozzolanic activity of calcined clay minerals: A comparison between kaolinite, illite and montmorillonite. Cem. Concr. Res. 2011, 41, 113-122. [CrossRef]

22. Minke, G. Building with Bamboo: Design and Technology of a Sustainable Architecture; Walter de Gruyter: Berlin, Germany, 2012.

23. Mostafa, N.Y.; Mohsen, Q.; El-Maghraby, A. Characterization of low-purity clays for geopolymer binder formulation. Int. J. Miner. Metall. Mater. 2014, 21, 609-619. [CrossRef]

24. Budelmann, H.; Hariri, K.; Krauss, H.-W.; Malonn, T. Effects of a clay additive on the properties of no-slump concrete. In Advances in Construction Materials; Springer: Berlin/Heidelberg, Germany, 2007; pp. 731-739.

25. Jasmund, K.; Lagaly, G. Tonminerale und Tone: Struktur, Eigenschaften, Anwendungen und Einsatz in Industrie und Umwelt; Springer: Berlin/Heidelberg, Germany, 2013. Available online: https:/ link.springer.com/book/10.1007/978-3-540-72448-3 (accessed on 27 September 2021).

26. Birdi, K. Handbook of Surface and Colloid Chemistry; CRC Press: Boca Raton, FL, USA, 2008.

27. Bergaya, F.; Theng, B.K.G.; Lagaly, G. Handbook of Clay Science; Elsevier: Amsterdam, The Netherlands, 2006.

28. Garg, N.; Skibsted, J. Pozzolanic reactivity of a calcined interstratified illite/smectite (70/30) clay. Cem. Concr. Res. 2016, 79, 101-111. [CrossRef]

29. Landrou, G.; Brumaud, C.; Winnefeld, F.; Flatt, R.J.; Habert, G. Lime as an anti-plasticizer for self-compacting clay concrete. Materials 2016, 9, 330. [CrossRef] [PubMed]

30. Guiliard, H.; Houben, H. Earth Construction, a Comprehensive Guide; Intermediate Technology Publications: London, UK, 1994; $112 p$.

31. Rossen, J.E. Composition and Morphology of CASH in Pastes of Alite and Cement Blended with Supplementary Cementitious Materials; EPFL: Lausanne, Switzerland, 2014.

32. Palomo, A.; Macias, A.; Blanco, M.; Puertas, F. Physical, Chemical and Mechanical Characterization of Geopolymers. In Proceedings of the 9th International Congress on the Chemistry of Cement, New Delhi, India, 1992; pp. 505-511. Available online: https:/ /iccc-online.org/fileadmin/gruppen/iccc/ICCC09_1992.pdf (accessed on 27 September 2021).

33. Zibouche, F.; Kerdjoudj, H.; de Lacaillerie, J.-B.d.E.; Van Damme, H. Geopolymers from Algerian metakaolin. Influence of secondary minerals. Appl. Clay Sci. 2009, 43, 453-458. [CrossRef]

34. Chareerat, T.; Lee-Anansaksiri, A.; Chindaprasirt, P. Synthesis of High Calcium Fly Ash and Calcined Kaoline Geopolymer Mortar. In Proceedings of the International Conference on Pozzolan, Concrete and Geopolymer, Khon Kaen, Thailand, 24-25 May 2006; pp. 24-25. 
35. Elimbi, A.; Tchakoute, H.; Njopwouo, D. Effects of calcination temperature of kaolinite clays on the properties of geopolymer cements. Constr. Build. Mater. 2011, 25, 2805-2812. [CrossRef]

36. He, C.; Osbaeck, B.; Makovicky, E. Pozzolanic reactions of six principal clay minerals: Activation, reactivity assessments and technological effects. Cem. Concr. Res. 1995, 25, 1691-1702. [CrossRef]

37. Habert, G.; Choupay, N.; Escadeillas, G.; Guillaume, D.; Montel, J.M. Clay content of argillites: Influence on cement based mortars. Appl. Clay Sci. 2009, 43, 322-330. [CrossRef]

38. Gao, X.; Kawashima, S.; Liu, X.; Shah, S.P. Influence of clays on the shrinkage and cracking tendency of SCC. Cem. Concr. Compos. 2012, 34, 478-485. [CrossRef]

39. Lei, L.; Plank, J. A study on the impact of different clay minerals on the dispersing force of conventional and modified vinyl ether based polycarboxylate superplasticizers. Cem. Concr. Res. 2014, 60, 1-10. [CrossRef]

40. Liu, X.; Wang, Z.M.; Wu, H.; Li, H.Q. Effects of clay on flow properties of polycarboxylate superplasticizer and its control measure. In Advanced Materials Research; Trans Tech Publications: Bäch, Switzerland, 2013; pp. 682-685.

41. Al-Akhras, N.M. Durability of metakaolin concrete to sulfate attack. Cem. Concr. Res. 2006, 36, 1727-1734. [CrossRef]

42. Poon, C.-S.; Azhar, S.; Anson, M.; Wong, Y.-L. Performance of metakaolin concrete at elevated temperatures. Cem. Concr. Compos. 2003, 25, 83-89. [CrossRef]

43. Qian, X.; Li, Z. The relationships between stress and strain for high-performance concrete with metakaolin. Cem. Concr. Res. 2001, 31, 1607-1611. [CrossRef]

44. Khatib, J. Metakaolin concrete at a low water to binder ratio. Constr. Build. Mater. 2008, 22, 1691-1700. [CrossRef]

45. Vejmelkova, E.; Pavlikova, M.; Keppert, M.; Keršner, Z.; Rovnaníková, P.; Ondráček, M.; Sedlmajer, M.; Černý, R. High performance concrete with Czech metakaolin: Experimental analysis of strength, toughness and durability characteristics. Constr. Build. Mater. 2010, 24, 1404-1411. [CrossRef]

46. Brooks, J.; Johari, M.M. Effect of metakaolin on creep and shrinkage of concrete. Cem. Concr. Compos. 2001, 23, 495-502. [CrossRef]

47. Güneyisi, E.; Mermerdaş, K. Comparative study on strength, sorptivity, and chloride ingress characteristics of air-cured and water-cured concretes modified with metakaolin. Mater. Struct. 2007, 40, 1161. [CrossRef]

48. Khatib, J.; Hibbert, J. Selected engineering properties of concrete incorporating slag and metakaolin. Constr. Build. Mater. 2005, 19, 460-472. [CrossRef]

49. Duan, P.; Shui, Z.; Chen, W.; Shen, C. Effects of metakaolin, silica fume and slag on pore structure, interfacial transition zone and compressive strength of concrete. Constr. Build. Mater. 2013, 44, 1-6. [CrossRef]

50. Cheng, S.; Shui, Z.; Sun, T.; Yu, R.; Zhang, G.; Ding, S. Effects of fly ash, blast furnace slag and metakaolin on mechanical properties and durability of coral sand concrete. Appl. Clay Sci. 2017, 141, 111-117. [CrossRef]

51. Reddy, M.A.K.; Rao, V.R. Utilization of Bentonite in concrete: A review. Int. J. Recent Technol. Eng. 2019, 7, 541-545.

52. Mirza, J.; Riaz, M.; Naseer, A.; Rehman, F.; Khan, A.; Ali, Q. Pakistani bentonite in mortars and concrete as low cost construction material. Appl. Clay Sci. 2009, 45, 220-226. [CrossRef]

53. Alaneme, G.U.; Mbadike, E.M. optimisation of strength development of bentonite and palm bunch ash concrete using fuzzy logic. Int. J. Sustain. Eng. 2021, 14, 1-17. [CrossRef]

54. Khushnood, R.A.; Rizwan, S.A.; Memon, S.A.; Tulliani, J.-M.; Ferro, G.A. Experimental investigation on use of wheat straw ash and bentonite in self-compacting cementitious system. Adv. Mater. Sci. Eng. 2014, 2014, 832508. [CrossRef]

55. Reddy, G.V.K.; Rao, V.R.; Reddy, M.A.K. Experimental Investigation of Strength Parameters of Cement and Concrete by Partial Replacement of Cement with Indian Calcium Bentonite. Int. J. Civ. Eng. Technol. 2017, 8, 512-518.

56. Targan, S..; Olgun, A.; Erdogan, Y.; Sevinc, V. Effects of supplementary cementing materials on the properties of cement and concrete. Cem. Concr. Res. 2002, 32, 1551-1558. [CrossRef]

57. Hamed, N.; El-Feky, M.; Kohail, M.; Nasr, E.-S.A. Effect of nano-clay de-agglomeration on mechanical properties of concrete. Constr. Build. Mater. 2019, 205, 245-256. [CrossRef]

58. Langaroudi, M.A.M.; Mohammadi, Y. Effect of nano-clay on workability, mechanical, and durability properties of selfconsolidating concrete containing mineral admixtures. Constr. Build. Mater. 2018, 191, 619-634. [CrossRef]

59. Hamed, N.; El-Feky, M.; Kohail, M.; Nasr, E.-S.A. Investigating the Effect of Nano Clay on Concrete-Rebars Bond Strength Modes. Int. J. Sci. Eng. Res. 2017, 8, 1621-1628.

60. Murat, M.; Comel, C. Hydration reaction and hardening of calcined clays and related minerals III. Influence of calcination process of kaolinite on mechanical strengths of hardened metakaolinite. Cem. Concr. Res. 1983, 13, 631-637. [CrossRef]

61. Badogiannis, E.; Kakali, G.; Tsivilis, S. Metakaolin as supplementary cementitious material. J. Therm. Anal. Calorim. 2005, 81, 457-462. [CrossRef]

62. Mejía de Gutiérrez, R.; Torres, J.; Vizcayno, C.; Castello, R. Influence of the calcination temperature of kaolin on the mechanical properties of mortars and concretes containing metakaolin. Clay Miner. 2008, 43, 177-183. [CrossRef]

63. Ilić, B.R.; Mitrović, A.A.; Miličić, L.R. Thermal treatment of kaolin clay to obtain metakaolin. Hem. Ind. 2010, 64, 351-356. [CrossRef]

64. Moodi, F.; Ramezanianpour, A.; Safavizadeh, A.S. Evaluation of the optimal process of thermal activation of kaolins. Sci. Iran. 2011, 18, 906-912. [CrossRef]

65. Salau, M.A.; Osemeke, O.J. Effects of Temperature on the Pozzolanic Characteristics of Metakaolin-Concrete. Phys. Sci. Int. J. 2015, 6, 131-143. [CrossRef] 
66. Albidah, A.; Altheeb, A.; Alrshoudi, F.; Abadel, A.; Abbas, H.; Al-Salloum, Y. Bond Performance of GFRP and Steel Rebars Embedded in Metakaolin Based Geopolymer Concrete, Structures; Elsevier: Amsterdam, The Netherlands, 2020; Volume 27, pp. 1582-1593.

67. Pusch, R. Bentonite Clay: Environmental Properties and Applications; CRC Press: Boca Raton, FL, USA, 2015.

68. Arslan, M.; Abdioğlu, E.; Kadir, S. Mineralogy, geochemistry, and origin of bentonite in Upper Cretaceous pyroclastic units of the Tirebolu area, Giresun, northeast Turkey. Clays Clay Miner. 2010, 58, 120-141. [CrossRef]

69. Maxim, L.D.; Niebo, R.; McConnell, E.E. Bentonite toxicology and epidemiology-A review. Inhal. Toxicol. 2016, 28, 591-617. [CrossRef]

70. Chakchouk, A.; Samet, B.; Mnif, T. Study on the potential use of Tunisian clays as pozzolanic material. Appl. Clay Sci. 2006, 33, 79-88. [CrossRef]

71. Sakizci, M.; Erdoğan Alver, B.; Yörükoğullari, E. Thermal behavior and immersion heats of selected clays from Turkey. J. Therm. Anal. Calorim. 2009, 98, 429-436. [CrossRef]

72. Taylor Lange, S.C. Advancements in Concrete Material Sustainability: Supplementary Cementitious Material Development and Pollutant Interaction. Ph.D. Thesis, University of Texas, Austin, TX, USA, May 2013.

73. Taylor-Lange, S.C.; Rajabali, F.; Holsomback, N.A.; Riding, K.; Juenger, M.C. The effect of zinc oxide additions on the performance of calcined sodium montmorillonite and illite shale supplementary cementitious materials. Cem. Concr. Compos. 2014, 53, 127-135. [CrossRef]

74. Tironi, A.; Trezza, M.A.; Scian, A.N.; Irassar, E.F. Assessment of pozzolanic activity of different calcined clays. Cem. Concr. Compos. 2013, 37, 319-327. [CrossRef]

75. Laske, S. Polymer Nanoclay Composites; William Andrew: Norwich, NY, USA, 2015.

76. Bojemueller, E.; Nennemann, A.; Lagaly, G. Enhanced pesticide adsorption by thermally modified bentonites. Appl. Clay Sci. 2001, 18, 277-284. [CrossRef]

77. De Paiva, L.B.; Morales, A.R.; Díaz, F.R.V. Organoclays: Properties, preparation and applications. Appl. Clay Sci. 2008, 42, 8-24. [CrossRef]

78. Kurecic, M.; Smole, M.S. Polymer nanocomposite hydrogels for water purification. Nanocomposites—New Trends Dev. 2012, 1, 161-185.

79. Montgomery, D.M.; Sollars, C.J.; Perry, R. Optimization of cement-based stabilization/solidification of organic-containing industrial wastes using organophilic clays. Waste Manag. Res. 1991, 9, 21-34. [CrossRef]

80. Kuo, W.-Y.; Huang, J.-S.; Lin, C.-H. Effects of organo-modified montmorillonite on strengths and permeability of cement mortars. Cem. Concr. Res. 2006, 36, 886-895. [CrossRef]

81. Kuo, W.-Y.; Huang, J.-S.; Yu, B.-Y. Evaluation of strengthening through stress relaxation testing of organo-modified montmorillonite reinforced cement mortars. Constr. Build. Mater. 2011, 25, 2771-2776. [CrossRef]

82. Papatzani, S.; Paine, K. Inorganic and organomodified nano-montmorillonite dispersions for use as supplementary cementitious materials-A novel theory based on nanostructural studies. Nanocomposites 2017, 3, 2-19. [CrossRef]

83. Sedaghat, S.; Golbaz, F. In situ oxidative polymerization of aniline in the presence of manganese dioxide and preparation of polyaniline $/ \mathrm{MnO}_{2}$ nanocomposite. J. Nanostruct. Chem. 2013, 3, 65. [CrossRef]

84. Pavlidou, S.; Papaspyrides, C. A review on polymer-layered silicate nanocomposites. Prog. Polym. Sci. 2008, 33, 1119-1198. [CrossRef]

85. Jawaid, M.; Qaiss, A.; Bouhfid, R. Nanoclay Reinforced Polymer Composites; Springer: Berlin/Heidelberg, Germany, 2016.

86. Kawashima, S.; Chaouche, M.; Corr, D.J.; Shah, S.P. Influence of purified attapulgite clays on the adhesive properties of cement pastes as measured by the tack test. Cem. Concr. Compos. 2014, 48, 35-41. [CrossRef]

87. Quanji, Z. Thixotropic Behavior of Cement-Based Materials: Effect of Clay and Cement Types; Iowa State University: Ames, IA, USA, 2010.

88. Mousavi, S.; Dehestani, M.; Mousavi, S. Bond strength and development length of glass fiber-reinforced polymer bar in unconfined self-consolidating concrete. J. Reinf. Plast. Compos. 2016, 35, 924-941. [CrossRef]

89. Mousavi, S.; Dehestani, M.; Mousavi, K. Bond strength and development length of steel bar in unconfined self-consolidating concrete. Eng. Struct. 2017, 131, 587-598. [CrossRef]

90. Mori, H. High fluidity concrete. J. Archit. Build. Soc. 1998, 113, 41-43.

91. Haiqiang, J.; Fall, M.; Cui, L. Yield stress of cemented paste backfill in sub-zero environments: Experimental results. Miner. Eng. 2016, 92, 141-150. [CrossRef]

92. Xiong, L.; Zheng, G.; Bi, Y.; Fu, C. Effect of Typical Clay Upon the Dispersion Performance of Polycarboxylate Superplasticizer. In Proceedings of the 2015 International Conference on Materials, Environmental and Biological Engineering, Guilin, China, 28-30 March 2015; Atlantis Press: Amsterdam, The Netherlands, 2015; pp. 226-229.

93. Wang, L.; Wang, D. Effects of clay on properties of polycarboxylate superplasticizer and solutions. J. Wuhan Univ. Technol. Mater. Sci. Ed. 2015, 30, 1167-1171. [CrossRef]

94. Tan, H.; Gu, B.; Ma, B.; Li, X.; Lin, C.; Li, X. Mechanism of intercalation of polycarboxylate superplasticizer into montmorillonite. Appl. Clay Sci. 2016, 129, 40-46. [CrossRef]

95. Malekani, K.; Rice, J.A.; Lin, J.-S. Comparison of techniques for determining the fractal dimensions of clay minerals. Clays Clay Miner. 1996, 44, 677-685. [CrossRef] 
96. Lei, L.; Plank, J. A concept for a polycarboxylate superplasticizer possessing enhanced clay tolerance. Cem. Concr. Res. 2012, 42, 1299-1306. [CrossRef]

97. Ng, S.; Plank, J. Interaction mechanisms between Na montmorillonite clay and MPEG-based polycarboxylate superplasticizers. Cem. Concr. Res. 2012, 42, 847-854. [CrossRef]

98. Ouellet-Plamondon, C.; Scherb, S.; Köberl, M.; Thienel, K.-C. Acceleration of cement blended with calcined clays. Constr. Build. Mater. 2020, 245, 118439. [CrossRef]

99. Lei, L.; Plank, J. Synthesis and properties of a vinyl ether-based polycarboxylate superplasticizer for concrete possessing clay tolerance. Ind. Eng. Chem. Res. 2014, 53, 1048-1055. [CrossRef]

100. Ouellet-Plamondon, C.M.; Stasiak, J.; Al-Tabbaa, A. The effect of cationic, non-ionic and amphiphilic surfactants on the intercalation of bentonite. Colloids Surf. A Physicochem. Eng. Asp. 2014, 444, 330-337. [CrossRef]

101. Pekmezci, B.Y.; Voigt, T.; Wang, K.; Shah, S.P. Low compaction energy concrete for improved slipform casting of concrete pavements. ACI Mater. J. 2007, 104, 251.

102. Kawashima, S.; Kim, J.H.; Corr, D.J.; Shah, S.P. Study of the mechanisms underlying the fresh-state response of cementitious materials modified with nanoclays. Constr. Build. Mater. 2012, 36, 749-757. [CrossRef]

103. Jarvis, P.; Jefferson, B.; Gregory, J.; Parsons, S.A. A review of floc strength and breakage. Water Res. 2005, 39, 3121-3137. [CrossRef] [PubMed]

104. Johnson, S.B.; Franks, G.V.; Scales, P.J.; Boger, D.V.; Healy, T.W. Surface chemistry-rheology relationships in concentrated mineral suspensions. Int. J. Miner. Process. 2000, 58, 267-304. [CrossRef]

105. Shaughnessy, R., III; Clark, P.E. The rheological behavior of fresh cement pastes. Cem. Concr. Res. 1988, 18, 327-341. [CrossRef]

106. Tregger, N.A.; Pakula, M.E.; Shah, S.P. Influence of clays on the rheology of cement pastes. Cem. Concr. Res. 2010, 40, 384-391. [CrossRef]

107. Ferron, R.D.; Shah, S.; Fuente, E.; Negro, C. Aggregation and breakage kinetics of fresh cement paste. Cem. Concr. Res. 2013, 50, 1-10. [CrossRef]

108. Kawashima, S.; Hou, P.; Corr, D.J.; Shah, S.P. Modification of cement-based materials with nanoparticles. Cem. Concr. Compos. 2013, 36, 8-15. [CrossRef]

109. Ronsoux, L.; Moevus, M.; Jorand, Y.; Maximilien, S.; Olagnon, C.; Anger, R.; Fontaine, L. Poured Earth as Concrete. In Terra 2012; Theme 6: Research Inm Aterials and Technology for Conservation and Contemporary Architecture; HAL: Lyon, France, 2012.

110. Ouellet-Plamondon, C.M.; Habert, G. Self-Compacted Clay based Concrete (SCCC): Proof-of-concept. J. Clean. Prod. 2016, 117, 160-168. [CrossRef]

111. Liu, M.; Hu, Y.; Lai, Z.; Yan, T.; He, X.; Wu, J.; Lu, Z.; Lv, S. Influence of various bentonites on the mechanical properties and impermeability of cement mortars. Constr. Build. Mater. 2020, 241, 118015. [CrossRef]

112. Møller, P.C.; Mewis, J.; Bonn, D. Yield stress and thixotropy: On the difficulty of measuring yield stresses in practice. Soft Matter 2006, 2, 274-283. [CrossRef] [PubMed]

113. Roussel, N. A thixotropy model for fresh fluid concretes: Theory, validation and applications. Cem. Concr. Res. 2006, 36, 1797-1806. [CrossRef]

114. Quanji, Z.; Lomboy, G.R.; Wang, K. Influence of nano-sized highly purified magnesium alumino silicate clay on thixotropic behavior of fresh cement pastes. Constr. Build. Mater. 2014, 69, 295-300. [CrossRef]

115. Voigt, T.; Malonn, T.; Shah, S.P. Green and early age compressive strength of extruded cement mortar monitored with compression tests and ultrasonic techniques. Cem. Concr. Res. 2006, 36, 858-867. [CrossRef]

116. Kuder, K.G.; Shah, S.P. Rheology of extruded cement-based materials. ACI Mater. J. 2007, 104, 283.

117. Krauss, H.W. Optimierung von Betonwaren Mittels Rheologischer Untersuchungen an Zusatzstoffen. Diploma Thesis, Institute of Molecular Biology of Barcelona (IBMB), Braunschweig, Germany, 2005.

118. Dejaeghere, I.; Sonebi, M.; De Schutter, G. Influence of nano-clay on rheology, fresh properties, heat of hydration and strength of cement-based mortars. Constr. Build. Mater. 2019, 222, 73-85. [CrossRef]

119. Wang, Y.; Jiang, Y.; Pan, T.; Yin, K. The Synergistic Effect of Ester-Ether Copolymerization Thixo-Tropic Superplasticizer and Nano-Clay on the Buildability of 3D Printable Cementitious Materials. Materials 2021, 14, 4622. [CrossRef]

120. Liu, Y.; Han, J.; Li, M.; Yan, P. Effect of a nanoscale viscosity modifier on rheological properties of cement pastes and mechanical properties of mortars. Constr. Build. Mater. 2018, 190, 255-264. [CrossRef]

121. Varela, H.; Barluenga, G.; Palomar, I. Influence of nanoclays on flowability and rheology of SCC pastes. Constr. Build. Mater. 2020, 243, 118285. [CrossRef]

122. Chen, M.; Yang, L.; Zheng, Y.; Huang, Y.; Li, L.; Zhao, P.; Wang, S.; Lu, L.; Cheng, X. Yield stress and thixotropy control of 3D-printed calcium sulfoaluminate cement composites with metakaolin related to structural build-up. Constr. Build. Mater. 2020, 252, 119090. [CrossRef]

123. Neto, J.d.S.A.; Santos, T.A.; de Andrade Pinto, S.; Dias, C.M.R.; Ribeiro, D.V. Effect of the combined use of carbon nanotubes (CNT) and metakaolin on the properties of cementitious matrices. Constr. Build. Mater. 2021, 271, 121903. [CrossRef]

124. Ferron, R.P.D. Formwork Pressure of Self-Consolidating Concrete: Influence of Flocculation Mechanisms, Structural Rebuilding, Thixotropy and Rheology. Ph.D. Thesis, Northwestern University, Evanston, IL, USA, December 2008.

125. Chang, T.-P.; Shih, J.-Y.; Yang, K.-M.; Hsiao, T.-C. Material properties of Portland cement paste with nano-montmorillonite. J. Mater. Sci. 2007, 42, 7478-7487. [CrossRef] 
126. Holt, E.E. Early Age Autogenous Shrinkage of Concrete; University of Washington: Washington, DC, USA, 2001.

127. Wongtanakitcharoen, T.; Naaman, A.E. Unrestrained early age shrinkage of concrete with polypropylene, PVA, and carbon fibers. Mater. Struct. 2007, 40, 289-300. [CrossRef]

128. Nehdi, M.; Soliman, A.M. Early-age properties of concrete: Overview of fundamental concepts and state-of-the-art research. Proc. Inst. Civ. Eng. Constr. Mater. 2011, 164, 57-77. [CrossRef]

129. Holt, E.; Leivo, M. Cracking risks associated with early age shrinkage. Cem. Concr. Compos. 2004, 26, 521-530. [CrossRef]

130. Mihashi, H.; Leite, J.P.D.B. State-of-the-art report on control of cracking in early age concrete. J. Adv. Concr. Technol. 2004, 2, 141-154. [CrossRef]

131. Esping, O. Early Age Properties of Self-Compacting Concrete-Effects of Fine Aggregate and Limestone Filler; Chalmers University of Technology: Gothenburg, Sweden, 2007.

132. Tazawa, E.-I. Autogenous Shrinkage of Concrete; CRC Press: Boca Raton, FL, USA, 1999.

133. Bentur, A. Early Age Cracking in Cementitious Systems: Report of RILEM Technical Committee 181-EAS'Early Age Shrinkage Induced Stresses and Cracking in Cementitious Systems; RILEM: Paris, France, 2003.

134. Kinuthia, J.; Wild, S.; Sabir, B.; Bai, J. Self-compensating autogenous shrinkage in Portland cement-Metakaolin-Fly ash pastes. Adv. Cem. Res. 2000, 12, 35-43. [CrossRef]

135. Bai, J.; Wild, S.; Ware, J.; Sabir, B. Using neural networks to predict workability of concrete incorporating metakaolin and fly ash. Adv. Eng. Softw. 2003, 34, 663-669. [CrossRef]

136. Akcay, B.; Tasdemir, M.A. Investigation of microstructure properties and early age behavior of cementitious materials containing metakaolin. In CONCREEP 10; American Society of Civil Engineers: Reston, VA, USA, 2015; pp. 1468-1475.

137. Akcay, B.; Tasdemir, M.A. In Investigation of Microstructure Properties and Early Age Behavior of Cementitious Materials Containing Metakaolin. In Proceedings of the 10th International Conference on Mechanics and Physics of Creep, Shrinkage, and Durability of Concrete and Concrete Structures, Vienna, Austria, 21-23 September 2015.

138. Gleize, P.J.; Cyr, M.; Escadeillas, G. Effects of metakaolin on autogenous shrinkage of cement pastes. Cem. Concr. Compos. 2007, 29, 80-87. [CrossRef]

139. Norvell, J.K.; Stewart, J.G.; Juenger, M.C.; Fowler, D.W. Influence of clays and clay-sized particles on concrete performance. J. Mater. Civ. Eng. 2007, 19, 1053-1059. [CrossRef]

140. Sabir, B.; Wild, S.; Bai, J. Metakaolin and calcined clays as pozzolans for concrete: A review. Cem. Concr. Compos. 2001, 23, 441-454. [CrossRef]

141. Budelmann, H.; Hariri, K.; Malonn, T. Ton als Betonzusatzstoff Produktqualität neu definiert. Betonw. Fert. Tech. 2006, 72, 92-94.

142. Buth, E.; Ivey, D.L.; Hirsch, T.J. Correlation of Concrete Properties with Tests for Clay Content of Aggregate; Texas Transportation Institute: San Antonio, TX, USA, 1964.

143. Yool, A.; Lees, T.; Fried, A. Improvements to the methylene blue dye test for harmful clay in aggregates for concrete and mortar. Cem. Concr. Res. 1998, 28, 1417-1428. [CrossRef]

144. Poon, C.-S.; Kou, S.; Lam, L. Compressive strength, chloride diffusivity and pore structure of high performance metakaolin and silica fume concrete. Constr. Build. Mater. 2006, 20, 858-865. [CrossRef]

145. Guneyisi, E.; Gesoglu, M.; Ozbay, E. Permeation properties of self-consolidating concretes with mineral admixtures. ACI Mater. J. 2011, 108, 150-158.

146. Ambroise, J.; Murat, M.; Pera, J. Hydration reaction and hardening of calcined clays and related minerals V. Extension of the research and general conclusions. Cem. Concr. Res. 1985, 15, 261-268. [CrossRef]

147. Pera, T.M.J.; Ambroise, J. Action of some aggressive solutions on Portland and calcined laterite blended cement concretes. Spec. Publ. 1992, 132, 763-780.

148. El-Din, H.K.S.; Eisa, A.S.; Aziz, B.H.A.; Ibrahim, A. Mechanical performance of high strength concrete made from high volume of Metakaolin and hybrid fibers. Constr. Build. Mater. 2017, 140, 203-209. [CrossRef]

149. Ding, J.-T.; Li, Z. Effects of metakaolin and silica fume on properties of concrete. ACI Mater. J. 2002, 99, $393-398$.

150. Xie, J.; Zhang, H.; Duan, L.; Yang, Y.; Yan, J.; Shan, D.; Liu, X.; Pang, J.; Chen, Y.; Li, X.; et al. Effect of nano metakaolin on compressive strength of recycled concrete. Constr. Build. Mater. 2020, 256, 119393. [CrossRef]

151. Güneyisi, E.; Gesoğlu, M.; Mermerdaş, K. Improving strength, drying shrinkage, and pore structure of concrete using metakaolin. Mater. Struct. 2008, 41, 937-949. [CrossRef]

152. Li, Z.; Ding, Z. Property improvement of Portland cement by incorporating with metakaolin and slag. Cem. Concr. Res. 2003, 33, 579-584. [CrossRef]

153. Masood, B.; Elahi, A.; Barbhuiya, S.; Ali, B. Mechanical and durability performance of recycled aggregate concrete incorporating low calcium bentonite. Constr. Build. Mater. 2020, 237, 117760. [CrossRef]

154. Trümer, A.; Ludwig, H.-M.; Schellhorn, M.; Diedel, R. Effect of a calcined Westerwald bentonite as supplementary cementitious material on the long-term performance of concrete. Appl. Clay Sci. 2019, 168, 36-42. [CrossRef]

155. Laidani, Z.E.-A.; Benabed, B.; Abousnina, R.; Gueddouda, M.K.; Kadri, E.-H. Experimental investigation on effects of calcined bentonite on fresh, strength and durability properties of sustainable self-compacting concrete. Constr. Build. Mater. 2020, 230, 117062. [CrossRef]

156. Xie, Y.; Li, J.; Lu, Z.; Jiang, J.; Niu, Y. Preparation and properties of ultra-lightweight EPS concrete based on pre-saturated bentonite. Constr. Build. Mater. 2019, 195, 505-514. [CrossRef] 
157. Yang, H.; Long, D.; Zhenyu, L.; Yuanjin, H.; Tao, Y.; Xin, H.; Jie, W.; Zhongyuan, L.; Shuzhen, L. Effects of bentonite on pore structure and permeability of cement mortar. Constr. Build. Mater. 2019, 224, 276-283. [CrossRef]

158. Hakamy, A.; Shaikh, F.; Low, I.M. Characteristics of nanoclay and calcined nanoclay-cement nanocomposites. Compos. Part. $B$ Eng. 2015, 78, 174-184. [CrossRef]

159. Wei, J.; Meyer, C. Sisal fiber-reinforced cement composite with Portland cement substitution by a combination of metakaolin and nanoclay. J. Mater. Sci. 2014, 49, 7604-7619. [CrossRef]

160. Rooj, S.; Das, A.; Heinrich, G. Tube-like natural halloysite/fluoroelastomer nanocomposites with simultaneous enhanced mechanical, dynamic mechanical and thermal properties. Eur. Polym. J. 2011, 47, 1746-1755. [CrossRef]

161. Farzadnia, N.; Ali, A.A.A.; Demirboga, R.; Anwar, M.P. Effect of halloysite nanoclay on mechanical properties, thermal behavior and microstructure of cement mortars. Cem. Concr. Res. 2013, 48, 97-104. [CrossRef]

162. Rao, C.N.R.; Kulkarni, G.U.; Thomas, P.J.; Edwards, P.P. Size-Dependent Chemistry: Properties of Nanocrystals. Chem. A Eur. J. 2001, 8, 28-35. [CrossRef]

163. Kamruzzaman, A.; Chew, S.; Lee, F. Microstructure of cement-treated Singapore marine clay. Proc. Inst. Civ. Eng. Ground Improv. 2006, 10, 113-123. [CrossRef]

164. Zhang, S.; Fan, Y.; Huang, J.; Shah, S.P. Effect of nano-metakaolinite clay on hydration behavior of cement-based materials at early curing age. Constr. Build. Mater. 2021, 291, 123107. [CrossRef]

165. Morsy, M.; Alsayed, S.; Aqel, M. Effect of nano-clay on mechanical properties and microstructure of ordinary Portland cement mortar. Int. J. Civ. Environ. Eng. 2010, 10, 21-25.

166. Hosseini, P.; Afshar, A.; Vafaei, B.; Booshehrian, A.; Molaei Raisi, E.; Esrafili, A. Effects of nano-clay particles on the short-term properties of self-compacting concrete. Eur. J. Environ. Civ. Eng. 2015, 21, 127-147. [CrossRef]

167. Norhasri, M.M.; Hamidah, M.; Fadzil, A.M. Inclusion of nano metaclayed as additive in ultra high performance concrete (UHPC). Constr. Build. Mater. 2019, 201, 590-598. [CrossRef]

168. Mehrabi, P.; Shariati, M.; Kabirifar, K.; Jarrah, M.; Rasekh, H.; Trung, N.T.; Shariati, A.; Jahandari, S. Effect of pumice powder and nano-clay on the strength and permeability of fiber-reinforced pervious concrete incorporating recycled concrete aggregate. Constr. Build. Mater. 2021, 287, 122652. [CrossRef]

169. Panda, B.; Lim, J.H.; Tan, M.J. Mechanical properties and deformation behaviour of early age concrete in the context of digital construction. Compos. Part. B Eng. 2019, 165, 563-571. [CrossRef]

170. Mousavi, S.S.; Ajarostaghi, S.S.M.; Bhojaraju, C. A critical review of the effect of concrete composition on rebar-concrete interface (RCI) bond strength: A case study of nanoparticles. SN Appl. Sci. 2020, 2, 893. [CrossRef]

171. Mousavi, S.S.; Guizani, L.; Bhojaraju, C.; Ouellet-Plamondon, C. The effect of air-entraining admixture and superabsorbent polymer on bond behaviour of steel rebar in pre-cracked and self-healed concrete. Constr. Build. Mater. 2021, 281, 122568. [CrossRef]

172. Karahan, O.; Hossain, K.M.; Ozbay, E.; Lachemi, M.; Sancak, E. Effect of metakaolin content on the properties self-consolidating lightweight concrete. Constr. Build. Mater. 2012, 31, 320-325. [CrossRef]

173. Sancak, E.; Hossain, K.M.A.; Lachemi, M. Bond loss between metakaolin-incorporated structural lightweight self-consolidating concrete and corroded steel reinforcement. J. Mater. Civ. Eng. 2017, 29, 4016283. [CrossRef]

174. Güneyisi, E.; Gesoğlu, M.; Akoi, A.O.M.; Mermerdaş, K. Combined effect of steel fiber and metakaolin incorporation on mechanical properties of concrete. Compos. Part. B Eng. 2014, 56, 83-91. [CrossRef]

175. Zhang, S.; Fan, Y.; Li, N. Bonding behavior between steel bars and concrete modified with nano-kaolinite clay. J. Southeast. Univ. Nat. Sci. Ed. 2015, 45, 382-386.

176. Fan, Y.F.; Zhang, S.Y.; Shah, S.P. Influence of Nanoclay on Concrete. In Key Engineering Materials; Trans Tech Publications: Zurich, Switzerland, 2016; pp. 256-262.

177. Zhang, S.; Fan, Y.; Jia, Z.; Ren, J. Effect of nano-kaolinite clay on rebar corrosion and bond behavior between rebar and concrete. J. Mater. Civ. Eng. 2021, 33, 4020416. [CrossRef]

178. Banthia, N.; Yan, C. Bond-slip characteristics of steel fibers in high reactivity metakaolin (HRM) modified cement-based matrices. Cem. Concr. Res. 1996, 26, 657-662. [CrossRef]

179. Lee, J.-W.; Park, C.-G. Bond properties of structural poly vinyl alcohol fiber in cement based composites with metakaolin and silica fume contents. J. Korean Soc. Agric. Eng. 2012, 54, 9-16.

180. Yalçinkaya, Ç.; Beglarigale, A.; Yazici, H. The effect of metakaolin and end type of steel fiber on fiber-SIFCON matrix bond characteristics. Usak Univ. J. Mater. Sci. 2014, 3, 97. [CrossRef]

181. Oh, R.-O.; Park, C.G. Pullout performance of reinforcing fiber embedded in nano materials cement mortar with nano clay contents. J. Korean Soc. Agric. Eng. 2013, 55, 113-121.

182. ACI. Guide to Durable Concrete; 201.2R-01; American Concrete Institute: Farmington Hills, MI, USA, 2001.

183. Tang, S.W.; Yao, Y.; Andrade, C.; Li, Z. Recent durability studies on concrete structure. Cem. Concr. Res. 2015, 78, 143-154. [CrossRef]

184. Turanli, L.; Bektas, F.; Monteiro, P. Use of ground clay brick as a pozzolanic material to reduce the alkali-Silica reaction. Cem. Concr. Res. 2003, 33, 1539-1542. [CrossRef]

185. Siddique, R.; Klaus, J. Influence of metakaolin on the properties of mortar and concrete: A review. Appl. Clay Sci. 2009, 43, 392-400. [CrossRef] 
186. Li, C.; Ideker, J.H.; Drimalas, T. The efficacy of calcined clays on mitigating alakli-silica reaction (ASR) in mortar and its influence on microstructure. In Calcined Clays for Sustainable Concrete; Springer: Berlin/Heidelberg, Germany, 2015; pp. $211-217$.

187. Waters, G.V.; Jones, T.R. Effect of metakaolin on ASR in concrete manufactured with reactive aggregates. In Proceedings of the 2nd International Conference on the Durability of Concrete, Montreal, QC, Canada, 4-9 August 1992; Volume 2, pp. 941-947.

188. Jones, T.; Walters, G.; Kostuch, J. Role of metakaolin in suppressing ASR in concrete containing reactive aggregate and exposed to saturated $\mathrm{NaCl}$ solution. In Proceedings of the 9th International Conference Alkali-Aggregate Reaction Concrete, London, UK, 27-31 July 1992; pp. 485-496.

189. Moser, R.D.; Jayapalan, A.R.; Garas, V.Y.; Kurtis, K.E. Assessment of binary and ternary blends of metakaolin and Class C fly ash for alkali-silica reaction mitigation in concrete. Cem. Concr. Res. 2010, 40, 1664-1672. [CrossRef]

190. Ramlochan, T.; Thomas, M.; Gruber, K.A. The effect of metakaolin on alkali-silica reaction in concrete. Cem. Concr. Res. 2000, 30, 339-344. [CrossRef]

191. Chappex, T. The Role of Aluminium from Supplementary Cementitious Materials in Controlling Alkali-Silica Reaction; EPFL: Lausanne, Switzerland, 2012.

192. Chappex, T.; Scrivener, K.L. The effect of aluminum in solution on the dissolution of amorphous silica and its relation to cementitious systems. J. Am. Ceram. Soc. 2013, 96, 592-597. [CrossRef]

193. Trümer, A.; Ludwig, H.-M. Sulphate and ASR resistance of concrete made with calcined clay blended cements. In Calcined Clays for Sustainable Concrete; Springer: Berlin/Heidelberg, Germany, 2015; pp. 3-9.

194. Lothenbach, B.; Scrivener, K.; Hooton, R. Supplementary cementitious materials. Cem. Concr. Res. 2011, 41, 1244-1256. [CrossRef]

195. Irshidat, M.R.; Al-Saleh, M.H.; Sanad, S. Effect of nanoclay on the expansive potential of cement mortar due to Alkali-Silica Reaction. ACI Mater. J. 2015, 112, 801. [CrossRef]

196. Gruber, K.; Ramlochan, T.; Boddy, A.; Hooton, R.; Thomas, M. Increasing concrete durability with high-reactivity metakaolin. Cem. Concr. Compos. 2001, 23, 479-484. [CrossRef]

197. Courard, L.; Darimont, A.; Schouterden, M.; Ferauche, F.; Willem, X.; Degeimbre, R. Durability of mortars modified with metakaolin. Cem. Concr. Res. 2003, 33, 1473-1479. [CrossRef]

198. Güneyisi, E.; Gesoğlu, M.; Mermerdaş, K. Strength deterioration of plain and metakaolin concretes in aggressive sulfate environments. J. Mater. Civ. Eng. 2010, 22, 403-407. [CrossRef]

199. Duan, P.; Yan, C.; Zhou, W. Influence of partial replacement of fly ash by metakaolin on mechanical properties and microstructure of fly ash geopolymer paste exposed to sulfate attack. Ceram. Int. 2016, 42, 3504-3517. [CrossRef]

200. Poursaee, A. Corrosion of steel in concrete structures. In Corrosion of Steel in Concrete Structures; Elsevier: Amsterdam, The Netherlands, 2016; pp. 19-33.

201. Güneyisi, E.; Gesoğlu, M.; Karaboğa, F.; Mermerdaş, K. Corrosion behavior of reinforcing steel embedded in chloride contaminated concretes with and without metakaolin. Compos. Part. B Eng. 2013, 45, 1288-1295. [CrossRef]

202. Keleştemur, O.; Demirel, B. Effect of metakaolin on the corrosion resistance of structural lightweight concrete. Constr. Build. Mater. 2015, 81, 172-178. [CrossRef]

203. Batis, G.; Pantazopoulou, P.; Tsivilis, S.; Badogiannis, E. The effect of metakaolin on the corrosion behavior of cement mortars. Cem. Concr. Compos. 2005, 27, 125-130. [CrossRef]

204. Amin, N.-U.; Alam, S.; Gul, S. Effect of thermally activated clay on corrosion and chloride resistivity of cement mortar. J. Clean. Prod. 2016, 111, 155-160. [CrossRef]

205. Aguirre-Guerrero, A.M.; Mejía-de-Gutiérrez, R.; Montês-Correia, M.J.R. Corrosion performance of blended concretes exposed to different aggressive environments. Constr. Build. Mater. 2016, 121, 704-716. [CrossRef]

206. Parande, A.K.; Babu, B.R.; Karthik, M.A.; Kumaar, K.D.; Palaniswamy, N. Study on strength and corrosion performance for steel embedded in metakaolin blended concrete/mortar. Constr. Build. Mater. 2008, 22, 127-134. [CrossRef]

207. Standard, Korea. KS F 2456: Standard Test Method for Resistance of Concrete to Rapid Freezing and Thawing; KS Korea: Seongnam-si, Korea, 2013.

208. Zhang, M.; Malhotra, V.M. Characteristics of a thermally activated alumino-silicate pozzolanic material and its use in concrete. Cem. Concr. Res. 1995, 25, 1713-1725. [CrossRef]

209. Kim, H.-S.; Lee, S.-H.; Moon, H.-Y. Strength properties and durability aspects of high strength concrete using Korean metakaolin. Constr. Build. Mater. 2007, 21, 1229-1237. [CrossRef]

210. Hassan, A.A.; Lachemi, M.; Hossain, K.M. Effect of metakaolin and silica fume on the durability of self-consolidating concrete. Cem. Concr. Compos. 2012, 34, 801-807. [CrossRef]

211. Fan, Y.; Zhang, S.; Wang, Q.; Shah, S.P. Effects of nano-kaolinite clay on the freeze-thaw resistance of concrete. Cem. Concr. Compos. 2015, 62, 1-12. [CrossRef]

212. Niu, X.J.; Li, Q.B.; Hu, Y.; Tan, Y.S.; Liu, C.F. Properties of cement-based materials incorporating nano-clay and calcined nano-clay: A review. Constr. Build. Mater. 2021, 284, 122820. [CrossRef]

213. Kawashima, S.; Wang, K.; Ferron, R.D.; Kim, J.H.; Tregger, N.; Shah, S. A review of the effect of nanoclays on the fresh and hardened properties of cement-based materials. Cem. Concr. Res. 2021, 147, 106502. [CrossRef]

214. Taklymi, S.M.Q.; Rezaifar, O.; Gholhaki, M. Investigating the properties of bentonite and kaolin modified concrete as a partial substitute to cement. SN Appl. Sci. 2020, 2, 2023. [CrossRef]

215. Haque, M. No-slump concrete with fine sand and clay. Cem. Concr. Res. 1981, 11, 531-539. [CrossRef] 
216. Pike, D. Methodologies for Assessing the Variability of Fines in Sands Used for Concretes and Mortars. Ph.D. Thesis, University of Reading, Reading, UK, 1992.

217. Moukwa, M.; Lewis, B.; Shah, S.; Ouyang, C. Effects of clays on fracture properties of cement-based materials. Cem. Concr. Res. 1993, 23, 711-723. [CrossRef]

218. Karatas, M.; Benli, A.; Arslan, F. The effects of kaolin and calcined kaolin on the durability and mechanical properties of self-compacting mortars subjected to high temperatures. Constr. Build. Mater. 2020, 265, 120300. [CrossRef]

219. Sabir, B.; Wild, S.; Khatib, J. On the workability and strength development of metakaolin concrete. Concr. Environ. Enhanc. Prot. 1996, 651-656.

220. Wild, S.; Khatib, J.; Jones, A. Relative strength, pozzolanic activity and cement hydration in superplasticised metakaolin con-crete. Cem. Concr. Res. 1996, 26, 1537-1544. [CrossRef]

221. Bai, J.; Sabir, B.; Wild, S.; Kinuthia, J. Strength development in concrete incorporating PFA and metakaolin. Mag. Concr. Res. 2000, 52, 153-162. [CrossRef]

222. Bai, J.; Wild, S.; Gailius, A. Accelerating Early Strength Development of Concrete Using Metakaolin as an admixture. Mater. Sci. 2004, 10, 338-344.

223. Homayoonmehr, R.; Ramezanianpour, A.A.; Mirdarsoltany, M. Influence of metakaolin on fresh properties, mechanical prop-erties and corrosion resistance of concrete and its sustainability issues: A review. J. Build. Eng. 2021, 44, 103011. [CrossRef]

224. Botassi dos Santos, S.; Pinto da Silva Filho, L.C.; Calmon, J.L. Early-Age Creep of Mass Concrete: Effects of Chemical and Min-eral Admixtures. ACI Mater. J. 2012, 109, 1.

225. Zuo, J.; Li, H.; Dong, B.; Wang, L. Effects of metakaolin on the mechanical and anticorrosion properties of epoxy emulsion cement mortar. Appl. Clay Sci. 2020, 186, 105431. [CrossRef]

226. Walters, G.V.; Jones, T.R. Effect of metakaolin on alkali-silica reaction (asr) in concrete manufactured with reactive aggregate. In Proceedings of the Durability of Concrete Second International Conference, Montreal, QC, Canada, 4-9 August 1991; Volume II.

227. Faizal, M.M.; Hamidah, M.; Norhasri, M.M.; Noorli, I.; Hafez, M.M.E. Chloride permeability of nanoclayed ultra-high performance concrete. In InCIEC 2014; Springer: Berlin/Heidelberg, Germany, 2015; pp. 613-623.

228. Shalby, O.B.; Elkady, H.M.; Nasr, E.A.R.; Kohail, M. Assessment of mechanical and fire resistance for hybrid nano-clay and steel fibres concrete at different curing ages. J. Struct. Fire Eng. 2019, 11, 189-203. [CrossRef]

229. Mahboubi, B.; Guo, Z.; Wu, H. Evaluation of durability behavior of geopolymer concrete containing Nano-silica and Nano-clay additives in acidic media. J. Civ. Eng. Mater. Appl. 2019, 3, 163-171.

230. Jafari, M.; Mozhdehi, A.M.; Ganjali, A.; Bamoharram, F.F. Nanoclay-Supported Preyssler Heteropolyacid (NCP): An Effective Nanocomposite to Improve the Compressive Strength of Concrete. J. Sci. Eng. Elites 2020, 5, 99-103.

231. Alani, N.Y.; Al-Jumaily, I.A.; Hilal, N. Effect of nanoclay and burnt limestone powder on fresh and hardened properties of self-compacting concrete. Nanotechnol. Environ. Eng. 2021, 6, 20.

232. Mirgozar Langaroudi, M.A.; Mohammadi, Y. Effect of nano-clay on the freeze-thaw resistance of self-compacting concrete con-taining mineral admixtures. Eur. J. Environ. Civ. Eng. 2019, 1-20. [CrossRef]

233. Naji, H.F.; Khalid, N.N.; Alsaraj, W.K. Influence of Nanoclay on the Behavior of Reinforced Concrete Slabs. In IOP Conference Series: Materials Science and Engineering; IOP Publishing: Bristol, UK, 2020; p. 12107.

234. Aly, M.; Hashmi, M.; Olabi, A.; Messeiry, M.; Hussain, A. Effect of nano clay particles on mechanical, thermal and physical behaviours of waste-glass cement mortars. Mater. Sci. Eng. A 2011, 528, 7991-7998. [CrossRef]

235. Kalpokaitè-Dičkuvienè, R.; Lukošiūtè, S.I.; Baltušnikas, A.; Čèsnienè, J. Structural observation of cement paste modified with hydrophobic organoclay. Constr. Build. Mater. 2021, 272, 121931. [CrossRef]

236. Gholinezhad, F.; Moghbeli, M.R.; Aghaei, A.; Allahverdi, A. Effect of organoclay reinforced acrylate latex particles on the ce-ment paste performance. J. Dispers. Sci. Technol. 2021, 42, 416-431. [CrossRef]

237. Kalpokaitė-Dičkuvienè, R.; Lukošiūtè, I.; Čèsnienè, J.; Brinkienė, K.; Baltušnikas, A. Cement substitution by organoclay-The role of organoclay type. Cem. Concr. Compos. 2015, 62, 90-96. [CrossRef]

238. Chamundeeswari, J. Experimental Study on Partial Replacement of Cement by Bentonite in Paverblock. Int. J. Eng. Trends Technol. 2012, 3, 41-47.

239. Ahmad, J.; Tufail, R.F.; Aslam, F.; Mosavi, A.; Alyousef, R.; Faisal Javed, M.; Zaid, O.; Khan Niazi, M.S. A step towards sustainable self-compacting concrete by using partial substitution of wheat straw ash and bentonite clay instead of cement. Sustainability 2021, 13, 824. [CrossRef]

240. Lee, H.H.; Wang, C.-W.; Chung, P.-Y. Experimental Study on the Strength and Durability for Slag Cement Mortar with Benton-ite. Appl. Sci. 2021, 11, 1176. [CrossRef]

241. Qiyami Taklymi, S.M.; Rezaifar, O.; Gholhaki, M. Utilization of bentonite as partial replacement of cement in low-strength concrete. J. Concr. Struct. Mater. 2020, 5, 25-40.

242. Ahad, M.Z.; Ashraf, M.; Kumar, R.; Ullah, M. Thermal, physico-chemical, and mechanical behaviour of mass concrete with hybrid blends of bentonite and fly ash. Materials 2019, 12, 60. [CrossRef] [PubMed]

243. Akbar, J.; Alam, B.; Ashraf, M.; Afzal, S.; Ahmad, A.; Shahzada, K. Evaluating the Effect of Bentonite on Strength and Durability of High Performance Concrete. Int. J. Adv. Struct. Geotech. Eng. 2013, 2, 3347.

244. Luo, J.; Li, C.; Ma, Y.; Wang, L. Bentonite replacing part of cement concrete for resistance to chloride ion attack. In Proceedings of the E3S Web of Conferences; EDP Sciences: Les Ulis, France, 2019; p. 3011. 
245. Nagar, P.A.; Gupta, N.; Kishore, K.; Parashar, A.K. Coupled effect of B. Sphaericus bacteria and calcined clay mineral on OPC concrete. Mater. Today Proc. 2021, 44, 113-117. [CrossRef]

246. Lopez, R.F. Calcined Clayey Soils as a Potential Replacement for Cement in Developing Countries. Ph.D. Thesis, Ecole Polytechnique Fédérale de Lausanne, Lausanne, Switzerland, 2009.

247. Al-Hammood, A.A.; Frayyeh, Q.J.; Abbas, W.A. Iraqi Bentonite as a Natural Pozzolan for Sustainable Concrete; University of Technology: Baghdad, Iraq, 2021.

248. Rehman, S.U.; Yaqub, M.; Noman, M.; Ali, B.; Ayaz Khan, M.N.; Fahad, M.; Muneeb Abid, M.; Gul, A. The influence of thermo-mechanical activation of bentonite on the mechanical and durability performance of concrete. Appl. Sci. 2019, 9, 5549. [CrossRef]

249. Thienel, K.-C.; Beuntner, N. Effects of Calcined Clay as Low Carbon Cementing Materials on the Properties of Concrete; University of Dundee-Concrete Technology: Dundee, UK, 2012.

250. Panda, B.; Ruan, S.; Unluer, C.; Tan, M.J. Improving the 3D printability of high volume fly ash mixtures via the use of nano attapulgite clay. Compos. B Eng. 2019, 165, 75-83. [CrossRef]

251. Chen, M.; Liu, B.; Li, L.; Cao, L.; Huang, Y.; Wang, S.; Zhao, P.; Lu, L.; Cheng, X. Rheological parameters, thixotropy and creep of 3D-printed calcium sulfoaluminate cement composites modified by bentonite. Compos. B Eng. 2020, 186, 107821. [CrossRef]

252. Chen, Y.; Chaves Figueiredo, S.; Yalçinkaya, Ç.; Çopuroğlu, O.; Veer, F.; Schlangen, E. The effect of viscosity-modifying admixture on the extrudability of limestone and calcined clay-based cementitious material for extrusion-based 3D concrete printing. Materials 2019, 12, 1374. [CrossRef]

253. Chen, Y.; Li, Z.; Chaves Figueiredo, S.; Çopuroğlu, O.; Veer, F.; Schlangen, E. Limestone and calcined clay-based sustainable cementitious materials for 3D concrete printing: A fundamental study of extrudability and early-age strength development. Appl. Sci. 2019, 9, 1809. [CrossRef]

254. Malaeb, Z.; Hachem, H.; Tourbah, A.; Maalouf, T.; El Zarwi, N.; Hamzeh, F. 3D Concrete printing: Machine and mix design. Int. J. Civ. Eng. Technol. 2015, 6, 14-22. 